7

8

9

10 \title{
using static and dynamic headspace conditions \\ Understanding the role of saliva on aroma release from wine by
}

5

6

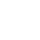

6

Carolina Muñoz-González ${ }^{1}$., Gilles Feron ${ }^{2}$, Elisabeth Guichard ${ }^{2}$, J. José RodríguezBencomo $^{1}$, Pedro J. Martín-Álvarez ${ }^{1}$, M. Victoria Moreno-Arribas ${ }^{1}$, Pozo-Bayón M. Ángeles* ${ }^{1}$ (1)

10
2 Centre des Sciences du Goût et de l'Alimentation, UMR1324 INRA, UMR6265 CNRS Université de Bourgogne, Agrosup Dijon, F-21000 Dijon, France Nicolás Cabrera 9, 28049, Madrid, Spain

3
Instituto de Investigación en Ciencias de la Alimentación (CIAL) (CSIC-UAM). C/ 
The aim of this work was to determine the role of saliva on wine aroma release by using static and dynamic headspace conditions. In the latter conditions, two different sampling points $(\mathrm{t}=0$ and $\mathrm{t}=10 \mathrm{~min})$ corresponding with oral $\left(25.5^{\circ} \mathrm{C}\right)$ and post-oral phases $\left(36^{\circ} \mathrm{C}\right)$ were monitored. Both methodologies were applied to reconstituted dearomatized white and red wines with different non-volatile wine matrix composition and a synthetic wine (without matrix effect). All the wines had the same ethanol concentration and were spiked with a mixture of forty five aroma compounds covering a wide range of physicochemical characteristics at typical wine concentrations. Two types of saliva (human and artificial) or control samples (water) were added to the wines. The adequacy of the two headspace methodologies for the purposes of the study (repeatability, linear ranges, determination coefficients, etc) was previously determined. After application of different chemometric analysis (ANOVA, LSD, PCA), results showed a significant effect of saliva on aroma release dependent on saliva type (differences between artificial and human) and on wine matrix using static headspace conditions. Red wines were more affected than white and synthetic wines by saliva, specifically human saliva, which provoked a reduction in aroma release for most of the assayed aroma compounds independent of their chemical structure. The application of dynamic headspace conditions using a saliva bioreactor at the two different sampling points $(t=0$ and $t=10$ min $)$ showed a lesser but significant effect of saliva than matrix composition and a high influence of temperature (oral and post-oral phases) on aroma release.

Key words: saliva, wine, aroma release, static HS-SPME-GC/MS, dynamic HS-SPME-GC/MS 
47 Aroma is one of the most outstanding aspects related to food preferences and choices, especially in the case of wine, in which consumption is mainly triggered by a hedonic motivation. Therefore, aroma represents a relevant aspect in wine research and many interesting works have focused in the characterization of aroma impact compounds of different wine types ${ }^{1-3}$. However, the retronasal aroma profile of a food during consumption might better represent the aroma fraction involved in the interaction with the olfactory receptors than the orthonasal aroma profile, therefore, it should be more closely related with aroma perception 4.

In the case of the consumption of liquid foods, such as wine, retronasal aroma is produced by the breathing airflow after swallowing sweeping the aroma molecules retained in the oral or throat cavities travelling via the nasopharynx from the mouth or throat to the nose ${ }^{5-7}$. It has been shown that orthonasal (odor sense when smelling a food) and retronasal aroma perception can be different ${ }^{8-10}$. Different factors involved in the intra-oral release of aroma compounds during consumption (saliva, interaction with mucosa, temperature, breathing flows, in-mouth air cavity volumes, change, etc.) seem to be related to these differences ${ }^{7,11-15} 16$.

Saliva is a complex dilute aqueous solution in which its composition varies depending on the respective physiological status, types of food consumed, oral hygiene, etc ${ }^{17}$. Saliva contains numerous inorganic salts (sodium, calcium, potassium, chloride, phosphate and bicarbonate) ${ }^{18}$ and organic components such as enzymes (amylase, lipases, proteases, etc.) ${ }^{17,19,20}$ and proteins (mucins, proline rich proteins, histidine rich proteins, etc) ${ }^{21,22}$. Previous studies have shown that saliva might exert an important role on aroma release through different physicochemical (dilution of aroma due to the aqueous phase of saliva, changes in the $\mathrm{pH}$ of the food, hydration 
of the food which favors aroma release, interaction with salts causing a salting out effect, interaction with proteins); chemical (degradation of odorants); biochemical (degradation of odorant or release from aroma precursors), or even physiological effects (impact on velumtongue seal formation and swallowing performance), which form part of many previous works performed on this topic ${ }^{19,20,23-25}$.

Nonetheless, many of the studies performed on the saliva effect on aroma release in simple and real food systems seem to be contradictory. Some studies have shown that saliva reduces aroma release: e.g. in pectin gels ${ }^{26}$ bell peppers ${ }^{25}$ or French beans ${ }^{24}$; whilst others have shown an increase in volatiles released from model gels ${ }^{27}$ or primary and multilayer oil/water emulsions ${ }^{28}$.There are also others works showing the lack of effect of saliva on aroma release: e.g. in model cheeses ${ }^{29}$ and from starch and water liquid systems ${ }^{30}$.

Undoubtedly, the physicochemical characteristics of the volatile compounds are outstanding parameters in determining the degree of interaction with saliva components ${ }^{22}$. In addition, saliva might induce an array of processes with sometimes opposite effects on aroma release and perception. Therefore, the overall impact of saliva needs to be specifically studied for each food system and aroma composition. Moreover, in many of the above mentioned works, different types of saliva had been used (human, artificial saliva with different compositions), therefore, a comparison of the effect of saliva performed in such different conditions is not straightforward.

As stated in a recent review on wine aroma analysis, the number of studies regarding aroma release during wine consumption using in vitro or in vivo approaches is scarce ${ }^{31}$, and research on the role of different intra-oral factors (such as saliva) which might be involved in aroma release during wine drinking is still incipient. The effect of saliva has been mainly studied because of its involvement in wine astringency ${ }^{32-37}$. However, there are very few studies 
92 focused on the role of saliva on wine aroma release ${ }^{38,39}$. Although the relatively short-intra-oral period of consumption of liquid foods, could indicate a limited effect of saliva on aroma release, the formation of intra-oral (and pharyngeal) aroma reservoir ${ }^{5}$ and the fact that natural swallowing of saliva is continuously performed, makes the idea that saliva might exert an important role in the perception of wine aroma during consumption perfectly viable, but also affecting the persistence of aroma perception during the post-oral phase of wine consumption. Very recently, using in vivo conditions, it was shown that enzymatic degradation of palm wine odorants due to saliva was not noticeable among pyrazines, pyrrolines and most alcohols but was quite pronounced among aldehydes, esters and thiols ${ }^{40}$.

Likewise, in other food systems, the few studies concerning the effect of saliva on aroma release from wines are contradictory. In the work of Genovese and collaborators ${ }^{38}$, saliva induced, in general, a decrease on aroma release for most of the wine volatiles, and this effect seemed to be more important in white than in red wines. On the contrary, Mitropoulou and coworkers $^{39}$, observed an enhancement on the release of hydrophobic compounds from model wines and a decrease in the release of the most hydrophilic compounds in the presence of saliva, although this effect was dependent on the concentration of tannins and polysaccharides. Both works were, however, performed in very different conditions; by using dynamic conditions in the work by Genovese et al.(2009) ${ }^{38}$, and by using a static headspace approach in the work of Mitropoulou et al.(2011) ${ }^{39}$. The dynamic conditions are advisable to achieve more realistic conditions to that accounting for during food consumption, however, the static conditions have been shown to be better suited for the study of interacting effects that otherwise might be underestimated with the first approach ${ }^{23,41}$.

Therefore, the aim of this work was to determine the role of saliva on wine aroma release by using both static and dynamic headspace conditions. In an attempt to follow a systematic study, 
avoiding the influence of different factors other than those of interest in this work (saliva effect

117 and wine type), both methodologies were applied to reconstituted wines (with different non-

118 volatile wine matrix composition) and a synthetic wine (with no matrix effect) keeping the 119 concentration of ethanol and aroma compounds the same. In addition, two types of saliva 120 (human and artificial) and control samples (with water) were used to better understand the 121 different mechanisms that saliva might induce on the release of aroma compounds from wine.

\section{MATERIAL AND METHODS}

\section{Wine samples}

124 Two commercial Spanish wines representative of different wine matrix compositions were 125 selected for this study: a young Verdejo white wine (W-wine), and a young Tempranillo red 126 wine (R-wine).

\section{Reconstituted wines}

Deodorization procedure

130 Wines were deodorized with Amberlite XAD-2 (Supelco, Bellefonte, PA, USA). Two 25 cm131 length glass columns (Pobel, Madrid, Spain), one for each wine type, filled with $100 \mathrm{~g}$ of 132 Amberlite XAD-2 were prepared by sequentially conditioning with $250 \mathrm{~mL}$ of 133 dichloromethane, then methanol and finally $375 \mathrm{~mL}$ of a $12 \%$ (v:v) hydroethanolic solution. 134 After this, wine samples were filtered through glass wool and loaded into the column by slowly 135 passing $750 \mathrm{~mL}$ of each wine. 
137 Deodorized wines ( $750 \mathrm{~mL}$ of each) were transferred to $250 \mathrm{~mL}$ vials and were completely 138 dried in a lyophiliser (Labconco, Kansas City, MO, USA). Five samples per wine type were 139 prepared using this procedure. To replace the oxygen from the samples, all the dry samples 140 were exposed to a Nitrogen atmosphere and stored at $4{ }^{\circ} \mathrm{C}$ until sample preparation. This 141 procedure practically ensured the complete elimination of the original aroma compounds in the wines as was confirmed by HS-SPME-GC/MS analysis.

\section{Wine reconstitution}

145 Deodorized wines were reconstituted with a hydroalcoholic solution and spiked with a volatile 146 mixture to a final ethanol concentration of $12 \%$. This aroma mixture composed of 45 aroma 147 compounds (manufacturers: Aldrich, Fluka, Merck, Firmenich, Lancaster and Scharlau) representative of a typical wine aroma profile to produce the final concentration of each aroma compound shown in Table 1. This table also shows some of the typical gas chromatography and physicochemical properties of these compounds.

151 As well as the two types of reconstituted wine matrix, a synthetic wine (S-wine) representing a 152 sample with 'no matrix effect' was prepared by mixing an hydroalcoholic solution with $4 \mathrm{~g} / \mathrm{L}$ 153 tartaric acid (Panreac, Barcelona, Spain) and adjusting the $\mathrm{pH}$ to 3.5 with $\mathrm{NaOH}$ (Panreac).

154 The influence of ethanol on the volatility of aroma compounds was not considered in this study, 155 since it has been extensively demonstrated ${ }^{42-45}$. Therefore, ethanol was kept at the same 156 concentration in all reconstituted and synthetic wines.

\section{Human saliva}


158 Stimulated human saliva was collected from 20 volunteers as described before ${ }^{46}$. Participants 159 could not consume food and water one hour before sampling. To stimulate production, 160 volunteers chewed a little piece of Parafilm ${ }^{\mathrm{TM}}$ and spat out as much saliva in a bottle as they 161 could. Sodium azide $\left(\mathrm{NaN}_{3}\right.$, Sigma-Aldrich, Saint Quentin Fallavier, France) was added at a 162 final concentration of $0.02 \%$ to avoid bacteria and fungi contamination and development. To obtain most representative salivary composition, the different saliva samples were pooled, mixed and centrifuged at $15000 \mathrm{~g}$ for $15 \mathrm{~min}$. After that, the salivary pool was filtered through a $0.22 \mu \mathrm{m}$ Sartorius device under vacuum at $4{ }^{\circ} \mathrm{C}$, to remove saliva bacteria. Finally, saliva was sampled into pots of $20 \mathrm{~mL}$ and stored at $-80^{\circ} \mathrm{C}$ until use.

Artificial saliva

Artificial saliva was prepared as previously described ${ }^{24}$ by dissolving in 1 L of water (purified by a Milli-Q system) $5.028 \mathrm{~g} \mathrm{NaHCO}_{3}, 1.369 \mathrm{~g} \mathrm{~K}_{2} \mathrm{HPO}_{4}$ x $3 \mathrm{H}_{2} \mathrm{O}, 0.877 \mathrm{~g} \mathrm{NaCl}, 0.477 \mathrm{KCl}$, $0.441 \mathrm{~g} \mathrm{CaCl}_{2} \times 2 \mathrm{H}_{2} \mathrm{O}$ and $2.16 \mathrm{~g}$ mucin (type 1-S from bovine submaxillary glands) from Sigma, (Milan, Italy). The artificial saliva was stored at $4{ }^{\circ} \mathrm{C}$ until use.

\section{Static Headspace-SPME sampling procedure}

In the human mouth, the average ratio liquid food/saliva had previously been shown to be $5 / 1$ $\mathrm{w} / \mathrm{v}^{38}$. Therefore, blends containing the reconstituted white and red wines (W-wine, $\mathrm{R}$-wine) or the synthetic wine (S-wine) were prepared by adding ten $\mathrm{mL}$ of the wines spiked with the volatile mixture in a $20 \mathrm{~mL}$ vial (Agilent Technologies, Palo Alto, CA, USA). After that, $2 \mathrm{~mL}$ of water, human or artificial saliva were added. The headspace vials were immediately closed with a screw cap and polytetrafluoroethylene (PTFE)/silicone septum (Supelco, Bellefonte, PA, USA) and were placed in the incubator of an automatic headspace sampling device (GERSTEL 
previously pre-incubated for $12 \mathrm{~min}$ at $36^{\circ} \mathrm{C}$. In the control wine, the extraction was performed in the headspace of each vial at different incubation times $(5,15,30$ and 45 minutes) to follow the kinetic of aroma release and to determine the equilibrium time, using a DVB/CAR/PDMS (Divinylbenzene/Carboxen/Polydimethylsiloxane 50/30 $\mu \mathrm{m}$ thickness $-2 \mathrm{~cm}$ length-) coated SPME fiber (Supelco, Bellefonte, PA). After the incubation time the fiber was exposed to the headspace above the sample for $2 \mathrm{~min}$, and the vial was maintained at $36{ }^{\circ} \mathrm{C}$. Desorption was performed in the injector of the GC system (Agilent $6890 \mathrm{~N}$ ) in splitless mode for $1.5 \mathrm{~min}$ at $270{ }^{\circ} \mathrm{C}$. After each injection the fiber was cleaned for $30 \mathrm{~min}$ to avoid any memory effect. Each analysis was performed in triplicate (one injection per sample vial). Linearity and reproducibility of the procedure were previously determined by using a synthetic wine spiked with different amounts of the aroma solution $(75,150$ and $300 \mu \mathrm{L})$ covering as closely as possible the wine aroma concentration expected in wines ${ }^{47}$.

The results of this study are shown in supplementary Table 1 in the Supporting information. Herein, satisfactory values for the regression coefficients for most of the aroma compounds were obtained, which ranged from 0.910 to 1.000 and the regression RSDs were also acceptable, with values lower than $20 \%$ (except for $\gamma$-butyrolactone and ethyl dodecanoate). These results confirmed the lack of interactions between individual volatile aroma compounds in the mixture at the concentrations used ${ }^{48}$, confirming the adequacy of the technique to perform this study.

\section{Dynamic Headspace-SPME sampling procedure}

201 A saliva bioreactor cell was used for these assays ${ }^{49}$. This device was specifically designed to 202 evaluate the particular role of saliva during liquid and semi-solid food consumption. It was 203 composed of a water-jacketed glass flask $(100 \mathrm{ml})$, which allowed a temperature control of the 
sample set at $36^{\circ} \mathrm{C}$. This device has five orifices. The first permits clean air to enter the flask to purge the sample $(100 \mathrm{~mL} / \mathrm{min})$, therefore, reproducing the dynamic conditions of the breathing phenomena. A second orifice is the purge gas outlet, which is connected through a heated transfer line to a flowmeter. In the third orifice the SPME fiber is inserted and the fourth opening is where the sample is introduced. Finally, in order to mix the sample as what might occur in the mouth, a fifth orifice allowed the introduction of a stir bar with digital speed control. An agitation rate of $150 \mathrm{rpm}$ was employed. This last orifice was firmly sealed around the stir bar shaft with a septum to avoid leaks from the flask. During the experiment setup, the sample was added to the apparatus using a glass funnel.

Following the above mentioned 5/1 average ratio liquid food/saliva in the human mouth, $10 \mathrm{ml}$ of water, human saliva or artificial saliva were transferred into the sample flask (100 ml) which was kept at $36{ }^{\circ} \mathrm{C}$, and then $50 \mathrm{~mL}$ of wine were then added. The headspace was continuously flushed with purified Nitrogen gas $(100 \mathrm{~mL} / \mathrm{min})$. Even if the experimental conditions were not directly comparable with conditions in the mouth, two sampling points were assayed to analyze the aroma release resulting from the incubation of control, red and white wines in contact with water, human saliva or artificial saliva (Figure 1). The first one, corresponding to an initial sampling time $(\mathrm{t}=0 \mathrm{~min})$, in which the saliva/wine mixture temperature raised from $25.5^{\circ} \mathrm{C}$ to $32.3{ }^{\circ} \mathrm{C}$ that might correspond with the introduction of the sample in the mouth (oral-phase). The second sampling point $\left(\mathrm{t}=10 \mathrm{~min}\right.$ at $\left.36{ }^{\circ} \mathrm{C}\right)$ was more related to the post-oral phase in which aroma from the remaining wine sample could be released within the oral cavity at physiological temperature. In both cases, extraction was performed for 2 minutes. Two or three replicates for each sample type were analyzed depending on the experiment.

226 It has been shown that inter-fiber repeatability is lower than the intra-fiber accuracy ${ }^{50-52}$.

227 Therefore, a preliminary inter-fiber repeatability study was performed in order to select the 
most similar fibers to complete the study. For this study nine SPME fibers were used to recover the 45 aroma compounds of the aroma mixture added to synthetic wines, and the two SPME fibers exhibiting the lowest variation (less than $10 \%$ RSDs for the extraction of the same aroma compound) were selected and used for the complete set of experiments.

In addition, because the dynamic HS-SPME sampling approach is based in a non-equilibrium situation, a linearity study was carried out in order to seek the relationship between the adsorbed amount of volatiles on the fiber and their initial concentration in the sample. To do so, a synthetic wine spiked with four different amounts of the aroma mixture, was submitted to the dynamic HS extraction conditions as explained above. These results are shown in the supplementary table 1 in the supporting information. As it can be seen there is good linearity, high coefficients of determination $\left(\mathrm{R}^{2}\right)$ (better than 0.9 in the assayed concentration range, except for $\gamma$-butyrolactone) and adequate regression RSDs for most of the assayed compounds independent of the time at which sampling was performed ( 0 and 10 minutes). The lack of fit test also showed the adequacy of the propose regression models ( $p$ values $>0.01$ for most of the aroma compounds) (data not shown). Therefore, the adsorbed amount of aroma compounds in the SPME was linearly proportional to their initial concentration in the sample matrix,

244 highlighting the adequacy of the technique for quantification purposes, which is in agreement with other theoretical and experimental studies performed in simpler aroma systems ${ }^{53}$.

\section{GC/MS analysis}

247 The identification of volatile compounds was carried out with a Gas Chromatograph Agilent 6890N coupled to a quadrupole Mass Detector Agilent 5973. After desorption of the SPME

249 fiber $\left(270{ }^{\circ} \mathrm{C}\right.$, splitless), volatile compounds were separated on a DB-Wax polar capillary 250 column $(60 \mathrm{~m} \times 0.25 \mathrm{~mm}$ i.d. $\times 0.50 \mu \mathrm{m}$ film thickness $)$ from Agilent $(J \& W$ Scientific, Folsom, 
251 USA). Helium was the carrier gas at a flow rate of $1 \mathrm{~mL} / \mathrm{min}$. The oven temperature was

252 initially held at $40{ }^{\circ} \mathrm{C}$ for $5 \mathrm{~min}$, then increased at $4{ }^{\circ} \mathrm{C} / \mathrm{min}$ to $240{ }^{\circ} \mathrm{C}$ and held for $20 \mathrm{~min}$.

253 For the MS system (Agilent 5973N), the temperatures of the transfer line, quadrupole and ion 254 source were 250,150 and $230{ }^{\circ} \mathrm{C}$ respectively. Electron impact mass spectra were recorded at $25570 \mathrm{eV}$ ionization voltages and the ionization current was $10 \mu \mathrm{A}$. The acquisitions were 256 performed in Scan (from 35 to $350 \mathrm{amu}$ ) and SIM modes for some specific compounds as 257 indicated in Table 1.

258 The identification of compounds was based on their retention indexes (RIs), comparison of 259 retention times and mass spectra. RIs were calculated from the retention times of n-alkanes 260 (C5-C30) on the same column. The mass spectra were compared with those from three databases: NIST 2.0, WILEY 138 and INRAMASS (internal database achieved using standard compounds).

To avoid possible wine matrix interaction phenomena ${ }^{47}$ instead of using an internal standard compound, release data were referred to absolute peak area, once the precision of the data was proven.

\section{Chemical wine matrix composition}

Total acidity and $\mathrm{pH}$, total polyphenols, neutral polysaccharides, residual sugar and nitrogen compounds (total nitrogen, free amino acids and peptides) were determined following 270 previously described analytical procedures ${ }^{47}$.

\section{Saliva biochemical analysis}


273 The protein concentration was determined using Bradford protein assay Quick Start (Bio-Rad,

274 France) with gamma-globulin as the standard for calibration.

275 Enzymatic activities

276 Lipolysis, proteolysis, lysozyme and amylase activities were measured as previously 277 described ${ }^{17,46}$.

\section{Statistical analysis}

279 Aroma release data (absolute peak area) were submitted to two-way ANOVA to determine significant effects of the studied factors (saliva type and wine type). In addition, for each aroma compound and wine type (red, white and synthetic) differences between medium type (with human saliva, artificial saliva and water) were subsequently examined by least significant difference (LSD) test. The significance level was $\mathrm{P}=0.05$ throughout the study. Principal component analysis (PCA) was also applied to examine the relationship between aroma release data and wine samples. The STATISTICA program for Windows version 7.1 was used for data processing (StatSoft, Inc., 2005, www.statsoft.com). Linear regression analysis to establish the calibration curves of each aroma compound and the lack of fit test to judge the adequacy of the models were performed by using the Statgraphics Centurion XV Version 15.2 (Manugistics, Rockville, MD, USA).

\section{RESULTS \& DISCUSSION}

291 To understand the effect of saliva composition on the release of aroma compounds, two types 292 of wines, a white and a red wine were previously deodorized, reconstituted to the same ethanol 293 content and aromatized at the same concentration with the aroma mixture (Table 1). With this procedure, it was guaranteed that ethanol did not affect the partition of volatile compounds into 
the headspace and that both wine matrices had the same concentration of aroma compounds. Therefore, the main differences between both wines were exclusively due to their matrix composition. Table 2 shows the chemical composition of both reconstituted wines. The percentage of non-volatile residue and the $\mathrm{pH}$ values were very similar. The non-volatile residue was $2.17 \%(\mathrm{w} / \mathrm{w})$ and $2.99 \%(\mathrm{w} / \mathrm{w})$ and the $\mathrm{pH}$ was 3.23 and 3.79 for the white and red wines respectively. Total acidity was slightly lower for the red wine ( $4.29 \mathrm{mg}$ tartaric acid/L) compared to $5.66 \mathrm{mg}$ tartaric acid/L in the case of white wine. The major differences were however, in the total polyphenol content, neutral polysaccharides, residual sugars and nitrogen containing compounds (amino acids and peptides) that were significantly higher in the red wine. These differences in matrix composition have been previously shown to affect the release of aroma compounds in static conditions ${ }^{47}$. In addition to this, a synthetic wine with the same ethanol concentration and $\mathrm{pH}=3.5$ that could be considered as a wine with "no matrix" effect was also prepared.

For the saliva experiments, two types of saliva were used, artificial saliva with mucin prepared in agreement with the recipe previously described and human saliva collected from different volunteers and mixed together to form a single pool. The composition, regarding total protein content and enzymes (amylase, lipase, lysozyme and protease) was analyzed. The major enzymatic activity detected in the human saliva was lysozyme $(698.06 \mathrm{U} / \mathrm{mL})$ followed by proteolysis $(16.77 \mathrm{U} / \mathrm{mL})$ and amylase $(8.01 \mathrm{U} / \mathrm{mL})$ and in a lesser extent lipase $(0.95 \mathrm{mU} / \mathrm{mL})$. These values are in the same order of magnitude to those previously published ${ }^{17,46,54}$ except for proteolysis activity, which was higher in our study. In addition to the two types of saliva, control experiments were also performed by adding the same amount of water instead of saliva. With this control, we also eliminated the dilution effect exerted by saliva on volatile release, which has also been described ${ }^{28,55}$. In addition, this type of experiment could provide us 
important information regarding whether saliva enzymes might have an impact on aroma release from wine as it has been previously shown in simple aroma/saliva mixtures ${ }^{19,20,56}$.

\section{Effect of saliva on aroma release using static headspace conditions}

Although static headspace conditions do not mimic the dynamic conditions accounting for during drinking or eating, this technique has been largely used to study aroma interactions with food matrix components to determine their effect on aroma release ${ }^{23,39,47,57}$. Even so, different authors have shown that this is a reliable approach to investigate partitioning in more controlled and simple conditions, which allows us to envisage this subtle phenomena with importance on aroma release, that otherwise might be underestimated by using dynamic HS methods ${ }^{23,41}$.

In this work, the aroma release behavior of a mixture of forty five volatile compounds characteristic of the wine aroma profile and with very different physicochemical characteristics (Table 1) was evaluated in presence and absence of human and artificial saliva by using a previously validated static HS-SPME approach (see Table 1 in supporting information). Preliminary experiments were performed in order to determine the equilibration time $(5,15,30$, 45 minutes) for most volatiles of the aroma mixture. From the analysis of the kinetic profiles it was found that five minutes of incubation was enough for the equilibration of most of the aroma compounds of the mixture. Only ten of them (ethyl propanoate, isobutyl acetate, isobutanol, isoamyl acetate, 1-butanol, ethyl octanoate, furfuryl alcohol, $\alpha$-terpineol, benzyl alcohol and decanoic acid) were not equilibrated after 5 minutes. Nonetheless, since the main objective of this work was to compare wine samples performed under identical experimental conditions, this should not be a constraint for the validity of the data and five minutes was adopted as the sampling time to perform the experiment, which are closer conditions to real physiological situations. 
342 Data corresponding to absolute peak areas of the aroma compounds determined by HS-SPME-

343 GC/MS analysis in the three types of wines (white, red and synthetic) incubated with the two

344 types of saliva (artificial and human) and water, were submitted to a two-factorial ANOVA to

345 determine the magnitude of the effect of matrix composition and type of saliva on aroma

346 release. Results of this analysis showed that both effects and the interactions (matrix

347 composition $x$ type of saliva) significantly affected the majority of aroma compounds. From a

348 total of forty five aroma compounds, thirty seven were affected by the type of saliva and thirty

349 three by matrix composition (data not shown). This showed the similar importance of both

350 factors on aroma release in static headspace conditions.

351 To gain insight on the impact of saliva on aroma release depending on wine matrix 352 composition, a LSD test was also carried out for each type of wine and for each aroma 353 compound. Table 3 shows these results taking into consideration the different aroma chemical 354 families assayed. As it can be seen, in general, the addition of saliva (artificial or human) provoked a significant decrease (or higher retention) on the aroma release for most of the aroma compounds assayed. However, the extent of this effect was dependent on the type of wine, but also on the type of aroma chemical class. In this sense, it is important to highlight that human saliva exerted a high impact on the aroma release from red wines and practically all the aroma compounds assayed were less released when human saliva was added to the wine. However, in the case of white wines this effect was more dependent on the type of aroma compound. For example, the addition of human or artificial saliva did not affect the release of any of the alcohols of the aroma mixture. As it can be seen in the table, the effect of saliva seemed to be much lower in the case of synthetic wines. aroma release behavior, a PCA was also performed taking into consideration all the aroma 
release data. Two principal components, $\mathrm{PC} 1$ and $\mathrm{PC} 2$ explaining $68.8 \%$ of data variations were obtained (Figure 2a). As it can be seen in the graph, PC1 was mainly involved in the separation of the samples depending on the type of medium (with human saliva, artificial saliva or water). In agreement with previous results, the clearest separation (or differences) among wine samples were obtained for red wines. As it can be seen, red wines with human saliva showed positive values for PC1 while red wines with water showed high and negative values for this component. Red wines with artificial saliva showed an intermediate behavior and were placed between the other two types of wine samples (with human saliva and water). PC1 was negatively correlated with many volatile compounds (twenty five volatile compounds showed loadings lower than 0.8 and fifteen of them lower than 0.9). Among them, the variable projection (Figure 2 b) showed that some aroma compounds such as limonene (11), hexyl acetate (14), cis-3-hexen-1-ol (17), linalool (20) or 5-methylfurfural (21) among others, were strongly correlated with PC1. On the contrary, PC2 separated wines in function of wine type. Red wines exhibited negative values for this component, whilst white and synthetic wines appeared on the half top of the graph showing positive values for PC2.

These results underlined an effect of saliva on aroma release dependent on wine matrix composition. Even more interestingly, red wines seemed to be more affected than white and global effect could be the result of the combination of single effects that could be differently affecting the volatile compounds employed in this study.

For instance, it is already known that wine polyphenols, which are more abundant and structurally different in red than in white wines, might interact with aroma compounds through different mechanisms depending on polyphenol structure decreasing the amount of aroma 
release $^{47,58-60}$. In addition to this effect, wine polyphenols (such as procyanidins) might form insoluble complexes with saliva proteins with colloidal structures ${ }^{39}$ modifying the viscosity of the sample, and therefore, affecting aroma release. To check this hypothesis, the viscosity values of white and red wines with the two types of saliva and water were also determined.

Table 4 shows that the viscosity values determined in all the wines were very similar ranging from $6.9 \mathrm{mPa}^{*} \mathrm{~s}$ for the white wine with water to $7.4 \mathrm{mPa}^{*} \mathrm{~s}$ for the white wine with artificial saliva. Therefore, there were not any substantial differences between red or white wines. Although an increase in viscosity induced by saliva has been proposed in order to explain the lower aroma release observe in oil/water emulsions ${ }^{12,28}$, the low volume of saliva compared to the wine (1:5) employed in this study, might not be enough to provoke a clear effect, at least in static headspace conditions as used here. Therefore, this factor did not seem a determinant parameter responsible for the higher retention of aroma compounds determined in red wines 402 and specifically in those with human saliva.

The buffering capacity of saliva might be another important factor to explain aroma release, since this property might induce changes in the $\mathrm{pH}$ of the food matrix ${ }^{12,22}$. In fact, this factor has been pointed out, since it might influence the overall perception of aroma compounds during the in vivo consumption of palm-wine ${ }^{61}$. To check this hypothesis, the $\mathrm{pH}$ values of the 407 human and artificial saliva and the $\mathrm{pH}$ values of the wine/saliva mixtures were determined and they are also shown in Table 4. The original $\mathrm{pH}$ value for the artificial saliva was a little bit higher (8.4) than the $\mathrm{pH}$ of the human saliva (8.2). As expected and for both white and red wines, the addition of water practically did not change the $\mathrm{pH}$ while it increased with the 411 addition of saliva. Artificial saliva seemed to induce higher changes in $\mathrm{pH}$ than human saliva 412 and this could be due to its higher original $\mathrm{pH}$ compared to the human saliva. Therefore, 
413 differences induced by changes in $\mathrm{pH}$ did not seem relevant to explain the differences in the 414 behavior of the aroma compounds in both wines whatever the matrix and the type of medium.

415 To explain the retention effect induced by saliva, mainly in red wines, we have to propose 416 additional hypothesis. Previous works using static headspace conditions but with other food 417 matrices have shown the ability of the saliva protein mucin to bind aroma compounds via hydrophobic interactions leading to a reduction in aroma release into the headspace ${ }^{23}$.

419 Moreover, this hypothesis has already been proposed to explain the lower release of a wide 420 range of volatile compounds (e.g. esters, acetates, alcohols) from red and white wines ${ }^{38}$. 421 However, in the present study, red wine with human saliva released lower amounts of aroma 422 than the same wine with artificial saliva. The final amount of mucin in the wine/artificial saliva vial was $4.32 \mathrm{mg}$, while the amount of total protein (including mucin) in the wines samples 424 added with human saliva was lower; $0.98 \mathrm{mg}$. Therefore, wines spiked with human saliva 425 should have a minor interaction effect with mucin (and therefore higher aroma release) than wines spiked with artificial saliva, which does not explain our results. However, it is important to bear in mind, that human saliva contains other proteins different to mucin, for instance, proline-rich proteins (PRPs), histidine rich proteins (histatins or HRPs), lactoferrine, and enzymes ( $\alpha$-amylase, lipase, etc $)^{21}$, which could be also involved in specific interactions with aroma compounds explaining the lower aroma release of wines with human saliva. In particular, PRPs, which represent up to $70 \%$ of proteins originated from the parotid gland, are known to interact with tannins leading to the formation of some aggregates ${ }^{62}$. Moreover, it has been shown that depending on the protein and tannin concentrations, dense aggregates might coexist with non-aggregated proteins, the latter also showing a significant number of bound tannin molecules ${ }^{62}$. We could hypothesize that the formation of this second type of aggregates might interact with aroma molecules without substantially changing the viscosity of the 
437 solution, as it was observed in the present study in the case of red wines added with human 438 saliva.

439 Moreover, besides tannins, other wine matrix components might be also involved in the 440 formation of these types of aggregates. Mitropoulou et al. (2011) ${ }^{39}$ have suggested, at least in 441 reconstituted model wines, the possible formation of saliva protein-polyphenol-carbohydrate 442 complexes able to encapsulate hydrophobic aroma molecules. In this sense, in addition to the 443 higher concentration of polyphenols determined in the red wine employed in this study, the 444 polysaccharide content was also higher (2502 mg mannose/L) compared to the white wines 445 (1667 mg mannose/L) (see Table 2). The formation of these type of complexes involving saliva proteins and specific wine polyphenols (tannins) and polysaccharides, both at higher concentrations in red than in white wines, might explain why red wines, and specifically those with human saliva retained more aroma molecules. Moreover, the fact that the very high hydrophobic aroma compounds $(\log P>2)$ of the aroma mixture showed higher retention (lower aroma release) in red wines with saliva than in the white wines, might be in agreement with this hypothesis. The formation of these structures (protein-polyphenol-carbohydrate complexes) might, however, represent a reservoir of aroma molecules ready to be released by the exhalation breath during the in vivo red wine consumption, as it has been recently 454 proposed $^{63}$.

Finally, the salivary metabolic activity might have also affected the release of certain aroma compounds. In this regard, a reduction of aldehydes to the corresponding alcohols and/or partial hydrolysis of certain aroma compounds such as esters might be expected ${ }^{19,20}$. In the case of the aldehydes employed in the aroma mixture (furfural and 5-methyl furfural), the release of these compounds was lower in red wines with human saliva, which could be in agreement with a possible transformation by an NADP-linked aldehyde reductase ${ }^{19}$. However, the increase of 
the corresponding alcohol (furfuryl alcohol in the case of furfural) was not significant in these samples. In addition, the involvement of aldehydes in the formation of condensation products such as Shiff bases (e.g. with salivary proteins) or other chemical reactions might be also possible $^{19}$.

On the other hand, a reduction of esters in the HS of white but mainly red wines with saliva has been also shown in this work. However, this seems to be more related to the interaction of these compounds with the complex protein-polyphenol-carbohydrate than related to the esterase activity of saliva. Although the decrease in the release of some esters (ethyl butanoate, hexanoate, octanoate, etc) in wines with human saliva compared to control wines (without saliva) has been attributed to the esterase activity ${ }^{38}$, the activity of these enzymes has only been

471 proven in a very different environment (specifically, in an aqueous system at $\mathrm{pH} 5)^{20}$ to that 472 accounted for in wine (12\% ethanolic system at $\mathrm{pH} 3.5$ ). Therefore, it seems difficult to obtain 473 straightforward relationships between the decrease in ester release and saliva esterase activity.

\section{Effect of saliva on aroma release using dynamic headspace conditions}

475 In the present work, aroma release from different wine matrices in dynamic conditions was determined by using a bioreactor cell with controlled temperature and agitation conditions at

477 two different sampling times (initial $t=0 \mathrm{~min}$ and final $\mathrm{t}=10 \mathrm{~min}$ ) (Figure 1). The initial 478 sampling time $(\mathrm{t}=0)$ might be related to the oral phase, in which the mixture of wine 479 (generally cold) and saliva is at lower temperature $\left(25.5^{\circ} \mathrm{C}\right)$ than physiological temperature $(36$ 480 $\left.{ }^{\circ} \mathrm{C}\right)$. The final sampling time $(\mathrm{t}=10)$ could be more representative of the post-oral phase, in which some volatiles could be released from the liquid sample remaining in the oral cavity after 482 drinking ${ }^{5}$ at oral temperature $\left(36^{\circ} \mathrm{C}\right)$. 
483 Aroma release data collected from $t=0$ and $t=10$ minutes are shown in Tables 5 and 6 484 respectively. These data were submitted to two independent two way ANOVA (one for each 485 sampling time), considering the global effect of saliva type (artificial, human, water) and type 486 of wine matrix (red, white, synthetic). Results showed that in the oral-phase $(\mathrm{t}=0)$ only nine 487 aroma compounds were affected by saliva type while thirty of them were affected by wine 488 matrix (data not shown). In addition, eleven compounds showed an effect of the interaction factor. In the case of the post-oral phase $(t=10$ minutes $)$ the application of the same statistical treatment also showed a higher influence of wine matrix composition (22 compounds significantly affected) compared to the saliva effect ( 7 compounds) and the interaction (5 492 compounds) (data not shown).

Compared to results from the previous static headspace analysis the influence of saliva on aroma release seemed to be lower. The minor effect of saliva addition by using the dynamic approach compared to the static headspace analysis could have been due to a displacement of the equilibrium, which might reduce the retention effect produced by proteins ${ }^{41}$ or by other non-volatile wine matrix molecules, such as the above mentioned protein-polyphenolpolysaccharides complexes. These findings are not surprising taking into consideration that several authors have already suggested that in spite that dynamic conditions might better 500 simulate the consumption situation, static measurements are better suited for determining 501 thermodynamic and kinetic parameters with good precision ${ }^{64}$.

502 In terms of amount of aroma release, it is interesting to notice that higher release for most of 503 the aroma compounds were found during the post-oral release step ( $\mathrm{t}=10$ minutes) (Table 6) 504 compared to the oral phase (Table 5). This could be due to the higher extraction temperature in the post-oral phase $\left(36^{\circ} \mathrm{C}\right)$ compared to the oral phase $\left(25.5^{\circ} \mathrm{C}\right)$. Previously, the effect of temperature $\left(4,23\right.$ and $\left.60{ }^{\circ} \mathrm{C}\right)$ on volatile release from oil/water emulsions using an artificial 
507 mouth system had been pointed out ${ }^{28}$. These authors showed a similar effect between 4 and 23

$508{ }^{\circ} \mathrm{C}$ (release less pronounced), compared to $60{ }^{\circ} \mathrm{C}$. In the present work, using more realistic 509 temperatures closer to what was expected during wine consumption $\left(25.5^{\circ} \mathrm{C}\right.$ and $\left.36{ }^{\circ} \mathrm{C}\right)$, most 510 of the volatile compounds showed higher release when the temperature raised about $12{ }^{\circ} \mathrm{C}$ 511 independent of the wine type. The increase in sampling temperature increases the partitioning 512 of the volatiles into the gas phase following the vant'Hoff's law ${ }^{65}$. In addition, in ethanol 513 solutions (as wine) and using dynamic headspace conditions, Tsachaki et al. (2008) ${ }^{66}$ showed 514 that the evaporation of ethanol at the solution vapor interface might create a surface tension 515 gradient, making new ethanol molecules move from the bulk phase to replenish the depleted 516 surface areas, carrying along an appreciable volume of underlying liquid with aroma 517 compounds. This phenomenon, called the Marangoni effect ${ }^{67}$, might also explain the higher 518 aroma release for most of the volatile compounds in the wines with a moderate increase in 519 temperature.

520 To extract more conclusions on the role of saliva on aroma release using dynamic conditions, a

521 LSD test for mean comparison was also performed for each type of wine (red, white and 522 artificial) in the oral and post-oral phases. These results are also shown in Tables 5 and 6. 523 Results show that during the oral-phase $(\mathrm{t}=0)$, only three terpenes $(\alpha$ - and $\beta$-pinene and 524 limonene) showed significant lower release in the three types of wines with saliva (human and 525 artificial) (Table 5). The same compounds were significantly less released in white and red 526 wines with saliva during the post-oral phase $(\mathrm{t}=10)$ (Table 6). These compounds are 527 characterized by high $\log P$ values, which seem to be in agreement with their involvement in 528 the formation of hydrophobic interactions with wine polyphenols ${ }^{58}$ or in their involvement in 529 the formation of complexes with salivary proteins, polyphenols and polysaccharides. 
530 Surprisingly and mainly during the oral-phase, a relatively high number of aroma compounds were highly released in the wines with saliva, which seem to contradict results from the previous experiment performed in static conditions. This could be due to the higher sensitivity

533 of the dynamic HS conditions over the static HS, which might have improved the detection of 534 some aroma compounds ${ }^{41}$. For instance, some lactones (cis- and trans- whiskylactones, $\gamma$ 535 nonalactone), furanic compounds (furfural, 5-methylfurfural), volatile phenols (eugenol, ethylphenol), C13 norisoprenoids ( $\beta$-damascenone, $\alpha$-ionone, $\beta$-ionone), and terpene alcohols 537 (linalool, terpinen-4-ol, $\alpha$-terpineol, $\beta$-citronellol, nerol) were more highly released in red wines with human saliva (Table 5)Some of these compounds such as terpene alcohols, could have 539 originated "de novo" from the corresponding grape glycosidic precursor that might have 540 remained in the wine matrix after the desaromatisation step. The existence of saliva glycoside 541 activity has been recently shown ${ }^{68}$.

542 In order to better understand the impact of saliva on aroma release in the three types of wine matrices, aroma release data (peak area) taken at $\mathrm{t}=0$ and $\mathrm{t}=10$ minutes were independently submitted to PCA. Figure 3a shows the representation of the two first principal components obtained after the application of this test to aroma release data collected from the wines at $\mathrm{t}=0$.

546 Both PCs explained more than $65 \%$ of data variation. As it can be seen (Figure 3), similarly to 547 what happens in static conditions, the main differences among wine samples were found in the case of red wines. PC1 clearly separated among red wines with water and artificial saliva from red wines with human saliva. The latter exhibited high and negative values for this component.

550 The representation of the variables on the basis of the two first components (Figure 3b) shows 551 how some variables such as trans and cis-hexenol (16, 17), linalool (20), 5-methylfurfural (21), 552 terpinen-4-ol (22), nerol (29), $\beta$-phenylethyl acetate (30), $\beta$-damascenone (32) and $\beta$-ionone 553 (38) among others, were strongly and negatively correlated with PC1. Most of these 
compounds match with those previously shown in the LSD test (Table 5), as significantly more released in red wines with saliva, which is the same conclusion obtained by PCA. In figure 3a, PC2 also shows a separation of the samples depending on wine matrix composition. Red wines appeared on the top of the graph showing high values for this component, whilst white and mainly synthetic wines appeared in the low part of the graph with lower and even negative values for this component, especially in the water medium. As it can be seen (Figure 3b), the most correlated (negatively) variables were -in general, ethyl esters such as ethyl octanoate (18), ethyl decanoate (23) and ethyl dodecanoate (31) and some nonalcoholic terpenes such $\alpha$ pinene (3), $\beta$-pinene (8) and limonene (11). It seems that these compounds (with high Log $\mathrm{P}$ value) might interact more with saliva protein and wine matrix than with synthetic wine. In the case of these three terpene compounds, this result was the same previously shown in the LSD test.

Similarly to the results found in the previous ANOVA and LSD test, results from the PCA performed with release data collected during the post-oral phase $(\mathrm{t}=10$ minutes $)$ did not show a clear grouping of wine samples depending on the medium composition (with human saliva, artificial saliva or water) (Figure 4a). However, an influence on the wine matrix composition was indeed manifested. As it can be seen, PC1 separates between red on the positive side of the graph and white and synthetic wines on the other side (Figure 4a) showing differences on their aroma release behavior. Red wines exhibited higher values for this component than white wines. The projection of the variables on the plane defined by the first and second components (Figure 4b) shows that PC1 was highly correlated (negatively) with some aroma compounds such as, terpinen-4-ol (22), $\beta$-citronellol (28), $\alpha$-ionone (33), $\beta$-phenylethyl alcohol (37), 4ethylguaicol (40) and 4-ethyl phenol (44), among others. In addition, PC2 also allowed a separation between synthetic wines with positive values for this component and white and red 
wines with negative values for it. In this case, PC2 was strongly and negatively correlated with some alcohols such as 1-butanol (10) or isoamylic alcohols (12) but positively with some nonalcoholic terpenes such as $\alpha$ - and $\beta$ - pinene $(3,8)$ and limonene (11).

In conclusion, the main finding of this work is that saliva has an important effect on aroma release from wine and this effect was different depending on wine matrix composition. In addition, we found differences depending on using human or artificial saliva, therefore proving that other proteins than mucins seem to have an important role on aroma release. Moreover, it has been shown that the effect of saliva on wine aroma release is more evident when using static than dynamic headspace conditions. In general, human saliva produces lower release for most of the wine volatile compounds, and this effect was more important in red than white wines. The interaction of aroma compounds with other proteins different to mucin and/or the formation of complexes involving saliva glycoproteins-wine polyphenols-wine polysaccharides and aroma compounds, preferentially for those aroma compounds with high $\log P$ values (hydrophobic), seem to be responsible for the observed effect In addition, large differences in the amount of aroma released depending on sampling temperature during the oral and post-oral phases invite us to think about the importance of this second step of wine consumption as a mechanism in releasing aroma compounds from oral or throat wine reservoirs influencing long lasting perception of aroma after swallowing. Finally, in spite of the minor impact of saliva observed in dynamic conditions, it is important to bear in mind that in vivo consumption conditions, could represent a more dynamic process to that used in the present work, in which saliva is continuously produced and replenished (incorporating more proteins to interact with aroma compounds, or enzymes) and also "fresh" sample is continuously being provided. Therefore, the extent of its effect could be higher than that determined with the experimental in vitro dynamic headspace conditions used in this study. On overall, this work will contribute to 


\section{ASSOCIATED CONTENT}

\section{* Supporting Information}

607 Table with the Linear ranges and regression parameters calculated for the aroma compounds by 608 using static and dynamic ( $\mathrm{t}=0$ and $\mathrm{t}=10$ minutes) HS-SPME-GC/MS approaches. This 609 material is available free of charge via the Internet at http://pubs.acs.org.

610

611

\section{AUTHOR INFORMATION}

\section{Corresponding author}

*Phone: +34 910017 961; Fax: +34 910017 905; e-mail: $\underline{\text { m.delpozo@csic.es }}$

\section{Funding sources}

This work was funded by the MINECO (AGL2012-04172-C02-01, and CONSOLIDER 616 INGENIO 2010 (FUN-C-FOOD, CSD2007-063, Projects). CMG would also like to thank 617 CSIC for its research contract cofunded by the European Social Fund together with Regional 618 Council for Burgundy and FEDER (European Union) for experiments realized in Dijon 619 (France).

\section{Notes}

621 The authors declare no competing financial interest.

\section{ACKNOWLEDGMENTS}

623 The Authors would like to give a special thank you to the technical assistance of Karine 624 Gourrat, Etienne Sémon and Hélène Brignot, to the volunteers for providing us the saliva 625 samples and to ChemoSens Platform (CSGA, Dijon, France). 
628 (1) Ferreira, V.; Ortin, N.; Escudero, A.; Lopez, R.; Cacho, J. Chemical characterization of 629 the aroma of Grenache rose wines: Aroma extract dilution analysis, quantitative determination, 630 and sensory reconstitution studies. J. Agric. Food Chem. 2002, 50, 4048-4054.

631 (2) Escudero, A.; Campo, E.; Farina, L.; Cacho, J.; Ferreira, V. Analytical characterization 632 of the aroma of five premium red wines. Insights into the role of odor families and the concept of fruitiness of wines. J. Agric. Food Chem. 2007, 55, 4501-4510.

(3) Guth, H. Identification of character impact odorants of different white wine varieties. $J$. Agric. Food Chem. 1997, 45, 3022-3026.

(4) Pierce, J.; Halpern, B. P. Orthonasal and retronasal odorant identification based upon vapor phase input from common substances. Chem. Senses 1996, 21, 529-543.

(5) Buettner, A.; Beer, A.; Hannig, C.; Settles, M. Observation of the swallowing process by application of videofluoroscopy and real-time magnetic resonance imaging-consequences for retronasal aroma stimulation. Chem. Senses 2001, 26, 1211-1219.

(6) Buettner, A.; Beer, A.; Hannig, C.; Settles, M.; Schieberle, P. Physiological and analytical studies on flavor perception dynamics as induced by the eating and swallowing process. Food Qual. Pref. 2002, 13, 497-504.

(7) Taylor, A. J. Volatile flavor release from foods during eating. Crit. Rev. Food Sci.Nutr. 1996, 36, 765-784.

(8) Linforth, R.; Martin, F.; Carey, M.; Davidson, J.; Taylor, A. J. Retronasal transport of aroma compounds. J. Agric. Food Chem. 2002, 50, 1111-1117.

(9) Voirol, E.; Daget, N. Comparative-study of nasal and retronasal olfactory perception. LWT-Food Sci. Technol. 1986, 19, 316-319.

(10) Burdach, K. J.; Kroeze, J. H. A.; Koster, E. P. Nasal, retronasal, and gustatory perception - an experimental comparison. Perception \& Psychophysics 1984, 36, 205-208.

(11) Buettner, A.; Schieberle, P. Exhaled odorant measurement (EXOM) - A new approach to quantify the degree of in-mouth release of food aroma compounds. LWT-Food Sci. Technol. 2000, 33, 553-559.

(12) Buettner, A.; Beauchamp, J. Chemical input - Sensory output: Diverse modes of physiology-flavour interaction. Food Qual. Pref. 2010, 21, 915-924.

(13) Burdach, K. J.; Doty, R. L. The effects of tongue movements and swallowing on retronasal aroma perception. Chem. Senses 1987, 12, 181-181.

(14) Overbosch, P.; Afterof, W. G.; Haring, P. G. Flavor release in the mouth. Food Rev. Int. 1991, 7, 137-184.

(15) Harrison, M. Effect of breathing and saliva flow on flavor release from liquid foods. $J$. Agric. Food Chem. 1998, 46, 2727-2735.

(16) Mishellany-Dutour, A.; Woda, A.; Laboure, H.; Bourdiol, P.; Lachaze, P.; Guichard, E.; Feron, G. Retro-Nasal Aroma Release Is Correlated with Variations in the In-Mouth Air Cavity Volume after Empty Deglutition. PLoS One 2012, 7, 8.

(17) Neyraud, E.; Palicki, O.; Schwartz, C.; Nicklaus, S.; Feron, G. Variability of human saliva composition: Possible relationships with fat perception and liking. Arch. Oral Biol. 2012, 57, 556-566.

(18) Drobitch, R. K.; Svensson, C. K. Therapeutic drug-monitoring in saliva - an update. Clin. Pharmacokinetics 1992, 23, 365-379.

(19) Buettner, A. Influence of human saliva on odorant concentrations. 2. aldehydes, alcohols, 3-alkyl-2-methoxypyrazines, methoxyphenols, and 3-hydroxy-4,5-dimethyl-2(5H)furanone. J. Agric. Food Chem. 2002, 50, 7105-7110. 
(20) Buettner, A. Influence of human salivary enzymes on odorant concentration changes occurring in vivo. 1. Esters and thiols. J. Agric. Food Chem. 2002, 50, 3283-3289. (21) McRae, J. M.; Kennedy, J. A. Wine and Grape Tannin Interactions with Salivary 2348-2364.

(22) Salles, C.; Chagnon, M.-C.; Feron, G.; Guichard, E.; Laboure, H.; Morzel, M.; Semon, E.; Tarrega, A.; Yven, C. In-Mouth Mechanisms Leading to Flavor Release and Perception. Crit. Rev. Food Sci. Nutr. 2011, 51, 67-90.

(23) Friel, E. N.; Taylor, A. J. Effect of salivary components on volatile partitioning from solutions. J. Agric. Food Chem. 2001, 49, 3898-3905.

(24) vanRuth, S. M.; Roozen, J. P.; Nahon, D. F.; Cozijnsen, J. L.; Posthumus, M. A. Flavour release from rehydrated French beans (Phaseolus vulgaris) influenced by composition and volume of artificial saliva. Z. Leben.Unters. For. 1996, 203, 1-6.

(25) van Ruth, S. M.; Buhr, K. Influence of saliva on temporal volatile flavour release from red bell peppers determined by proton transfer reaction-mass spectrometry. Eur. Food Res. Technol. 2003, 216, 220-223.

(26) Hansson, A.; Giannouli, P.; Van Ruth, S. The influence of gel strength on aroma release from pectin gels in a model mouth and in vivo, monitored with proton-transfer-reaction mass spectrometry. J. Agric. Food Chem. 2003, 51, 4732-4740.

(27) Boland, A. B.; Buhr, K.; Giannouli, P.; van Ruth, S. M. Influence of gelatin, starch, pectin and artificial saliva on the release of 11 flavour compounds from model gel systems. Food Chem. 2004, 86, 401-411.

(28) Benjamin, O.; Silcock, P.; Beauchamp, J.; Buettner, A.; Everett, D. W. Tongue Pressure and Oral Conditions Affect Volatile Release from Liquid Systems in a Model Mouth. J. Agric. Food Chem. 2012, 60, 9918-9927.

(29) Pionnier, E.; Nicklaus, S.; Chabanet, C.; Mioche, L.; Taylor, A. J.; Le Quere, J. L.; Salles, C. Flavor perception of a model cheese: relationships with oral and physico-chemical parameters. Food Qual. Pref. 2004, 15, 843-852.

(30) Rabe, S.; Linforth, R. S. T.; Krings, U.; Taylor, A. J.; Berger, R. G. Volatile release from liquids: A comparison of in vivo APCI-MS, in-mouth headspace trapping and in vitro mouth model data. Chem. Senses 2004, 29, 163-173.

(31) Muñoz-Gonzalez, C.; Rodriguez-Bencomo, J. J.; Moreno-Arribas, M. V.; Pozo-Bayon, M. A. Beyond the characterization of wine aroma compounds: looking for analytical approaches in trying to understand aroma perception during wine consumption. Analytical and Bioanal. Chem. 2011, 401, 1497-1512.

(32) Cala, O.; Dufourc, E. J.; Fouquet, E.; Manigand, C.; Laguerre, M.; Pianet, I. The Colloidal State of Tannins Impacts the Nature of Their Interaction with Proteins: The Case of Salivary Proline-Rich Protein/Procyanidins Binding. Langmuir 2012, 28, 17410-17418.

(33) Rinaldi, A.; Gambuti, A.; Moio, L. Precipitation of Salivary Proteins After the Interaction with Wine: The Effect of Ethanol, pH, Fructose, and Mannoproteins. J. Food Sci. 2012, 77, 485-490.

(34) de Freitas, V.; Mateus, N. Protein/Polyphenol Interactions: Past and Present Contributions. Mechanisms of Astringency Perception. Curr. Org. Chem. 2012, 16, 724-746.

(35) Mateus, N.; Pinto, R.; Ruao, P.; de Freitas, V. Influence of the addition of grape seed procyanidins to Port wines in the resulting reactivity with human salivary proteins. Food Chem. 2004, 84, 195-200. 
(36) Simon, C.; Barathieu, K.; Laguerre, M.; Schmitter, J. M.; Fouquet, E.; Pianet, I.; Dufourc, E. J. Three-dimensional structure and dynamics of wine tannin-saliva protein complexes. A multitechnique approach. Biochem.2003, 42, 10385-10395.

(37) Kallithraka, S.; Bakker, J.; Clifford, M. N.; Vallis, L. Correlations between saliva protein composition and some T-I parameters of astringency. Food Qual. Prefer. 2001, 12, 145-152. white and red wine in a model mouth system. Investigating the influence of saliva on volatile compound concentrations. Food Chem. 2009, 114, 100-107.

(39) Mitropoulou, A.; Hatzidimitriou, E.; Paraskevopoulou, A. Aroma release of a model wine solution as influenced by the presence of non-volatile components. Effect of commercial tannin extracts, polysaccharides and artificial saliva. Food Res. Int. 2011, 44, 1561-1570.

(40) Lasekan, O.,A Comparative Analysis of the Influence of Human Salivary Enzymes on Odorant Concentration in Three Palm Wines. Molecules 2013, 18, 11809-11823.

(41) Fabre, M.; Aubry, V.; Guichard, E. Comparison of different methods: Static and dynamic headspace and solid-phase microextraction for the measurement of interactions between milk proteins and flavor compounds with an application to emulsions. J. Agric. Food Chem. 2002, 50, 1497-1501.

(42) Escalona, H.; Piggott, J. R.; Conner, J. M.; Paterson, A. Effect of ethanol strength on the volatility of higher alcohols and aldehydes. Ital. J. Food Sci. 1999, 11, 241-248.

(43) Robinson, A. L.; Ebeler, S. E.; Heymann, H.; Boss, P. K.; Solomon, P. S.; Trengove, R. D. Interactions between Wine Volatile Compounds and Grape and Wine Matrix Components Influence Aroma Compound Headspace Partitioning. J. Agric. Food Chem. 2009, 57, 1031310322.

(44) Rodriguez-Bencomo, J. J.; Conde, J. E.; Rodriguez-Delgado, M. A.; GarciaMontelongo, F.; Perez-Trujillo, J. P. Determination of esters in dry and sweet white wines by headspace solid-phase microextraction and gas chromatography. J. Chromatogr. A 2002, 963, 213-223.

(45) Conner, J. M.; Birkmyre, L.; Paterson, A.; Piggott, J. R. Headspace concentrations of ethyl esters at different alcoholic strengths. J. Sci. Food Agric. 1998, 77, 121-126.

(46) Poette, J.; Mekoué, J.; Neyraud, E.; Berdeaux, O.; Renault, A.; Guichard, E.; Genot, C.; Feron, G. Fat sensitivity in humans: oleic acid detection threshold is linked to saliva composition and oral volume. Flavour Fragr. J. 2014, 29, 39-49.

(47) Rodriguez-Bencomo, J. J.; Muñoz-Gonzalez, C.; Andujar-Ortiz, I.; Jose MartinAlvarez, P.; Moreno-Arribas, M. V; Pozo-Bayon, M. A. Assessment of the effect of the nonvolatile wine matrix on the volatility of typical wine aroma compounds by headspace solid phase microextraction/gas chromatography analysis. J. Sci. Food Agric. 2011, 91, 2484-2494.

(48) Lubbers, S.; Decourcelle, N.; Vallet, N.; Guichard, E. Flavor release and rheology behavior of strawberry fatfree stirred yogurt during storage. J. Agric. Food Chem. 2004, 52, 3077-3082.

(49) Poette, J.; Lubbers, S.; Maison, B.; Andriot, I.; Pernin, K.; Guichard, E.; Cavellec, A.; Feron, G. The salivary reactor: an innovating tool for the categorization of food products through their aroma and taste compounds release profiles. In Advances and challenges in flavor chemistry \& biology. Proceedings of the 9th Wartburg Symposium, Hofmann, T.; Meyerhof, W.; Schieberle, P., Eds. Deutsche Forschungsanstalt für Lebensmittelchemie: Freising (Germany), 2010; pp 386-389. 
(50) Natera Marin, R.; Castro Mejias, R.; De Valme Garcia Moreno, M.; Garcia Rowe, F.; Garcia Barroso, C. Headspace solid-phase microextraction analysis of aroma compounds in vinegar. Validation study. J. Cromatogr.A 2002, 967, 261-7.

(51) Popp, P.; Paschke, A. Solid phase microextraction of volatile organic compounds using carboxen-polydimethylsiloxane fibers. Chromatographia 1997, 46, 419-424.

(52) Yang, S. S.; Huang, C. B.; Smetena, I. Optimization of headspace sampling using solidphase microextraction for volatile components in tobacco. J. Chromatogr. A 2002, 942, 33-39.

(53) Ai, J. Solid phase microextraction for quantitative analysis in nonequilibrium situations. Anal. Chem. 1997, 69, 1230-1236.

(54) Mounayar, R.; Septier, C.; Chabanet, C.; Feron, G.; Neyraud, E. Oral fat sensitivity in humans: links to saliva composition before and after stimulation by oleic acid. Chemosens. Percept. 2013, 6, 118-126.

(55) van Ruth, S. M.; Grossmann, I.; Geary, M.; Delahunty, C. M. Interactions between artificial saliva and 20 aroma compounds in water and oil model systems. J. Agric. Food Chem. 2001, 49, 2409-2413.

(56) Hussein, M. M.; Kachikian, R.; Pidel, A. R. Analysis for flavor residuals in the mouth by gas-chromatography. J. Food Sci. 1983, 48, 1884-1885.

(57) Kopjar, M.; Andriot, I.; Saint-Eve, A.; Souchon, I.; Guichard, E. Retention of aroma compounds: an interlaboratory study on the effect of the composition of food matrices on thermodynamic parameters in comparison with water. J. Sci. Food Agric. 2010, 90, 1285-1292.

(58) Dufour, C.; Bayonove, C. Interactions between Wine Polyphenols and Aroma Substances. An Insight at the Molecular Level. J. Agric. Food Chem. 1999, 47, 678-684.

(59) Jung, D. M.; de Ropp, J. S.; Ebeler, S. E., Study of interactions between food phenolics and aromatic flavors using one- and two-dimensional H-1 NMR spectroscopy. J. Agric. Food Chem. 2000, 48, 407-412.

(60) Aronson, J.; Ebeler, S. E. Effect of Polyphenol compounds on the headspace volatility of flavors. Am. J. Enol. Viticul. 2004, 55, 13-21.

(61) Lasekan, O.; Buettner, A.; Christlbauer, M. Investigation of the retronasal perception of palm wine ( Elaeis guineensis) aroma by application of sensory analysis and exhaled odorant measurement (EOM). Afr. J. Food Agric. Nutr. Develop. 2009, 9, 793-813.

(62) Canon, F.; Pate, F.; Cheynier, V.; Sarni-Manchado, P.; Giuliani, A.; Perez, J.; Durand, D.; Li, J.; Cabane, B., Aggregation of the Salivary Proline-Rich Protein IB5 in the Presence of the Tannin EgCG. Langmuir 2013, 29, 1926-1937.

(63) Muñoz-Gonzalez, C.; Martin-Alvarez, P. J.; Victoria Moreno-Arribas, M.; Angeles Pozo-Bayon, M. Impact of the Nonvolatile Wine Matrix Composition on the In Vivo Aroma Release from Wines. J. Agric. Food Chem. 2014, 62, 66-73.

(64) Juteau, A.; Cayot, N.; Chabanet, C.; Doublier, J. L.; Guichard, E. Flavour release from polysaccharide gels: different approaches for the determination of kinetic parameters. Trends Food Sci. Technol. 2004, 15, 394-402.

(65) Tromelin, A.; Andriot, I.; Kopjar, M.; Guichard, E. Thermodynamic and Structure Property Study of Liquid-Vapor Equilibrium for Aroma Compounds. J. Agric. Food Chem. 2010, 58, 4372-4387.

(66) Tsachaki, M.; Gady, A. L.; Kalopesas, M.; Linforth, R. S. T.; Athes, V.; Marin, M.; Taylor, A. J. Effect of ethanol, temperature, and gas flow rate on volatile release from aqueous solutions under dynamic headspace dilution conditions. J. Agric. Food Chem. 2008, 56, 53085315.

(67) Spedding, P. L.; Grimshaw, J.; Ohare, K. D. Abnormal evaporation rate of ethanol from low concentration aqueous-solutions. Langmuir 1993, 9, 1408-1413. 
814 (68) Mayr, C. M.; Parker, M.; Baldock, G. A.; Black, C. A.; Pardon, K. H.; Williamson, P. 815 O.; Herderich, M. J.; Francis, I. L. Determination of the Importance of In-Mouth Release of 816 Volatile Phenol Glycoconjugates to the Flavor of Smoke-Tainted Wines. J. Agric. Food Chem. $817 \quad \mathbf{2 0 1 4}, 62,2327-2336$.

818

819

820 


\section{FIGURE CAPTIONS}

822 Figure 1. Representation of the sampling procedure employed during the dynamic HS-SPME823 GC/MS analysis.

824 Figure 2. Graphic representation of the wine samples (2a) and of the variables (2b) obtained 825 using PCA with the aroma release data from the static HS-SPME-GC/MS. Numbers of the 826 variables in Figure $2 \mathrm{~b}$ correspond to the compounds listed in Table 1. RW, SW and WW mean 827 red, synthetic and white wines respectively.

828 Figure 3. Graphic representation of the wine samples (2a) and of the variables (2b) obtained 829 using PCA with the aroma release data from the dynamic HS-SPME-GC/MS analysis at $\mathrm{t}=0$ 830 (oral phase). Numbers of the variables in Figure $3 \mathrm{~b}$ correspond to the compounds listed in 831 Table 1.

832 Figure 4. PCA of the Graphic representation of the wine samples (2a) and of the variables (2b) 833 obtained using PCA with the aroma release data from the dynamic HS-SPME-GC/MS analysis 834 at $\mathrm{t}=10$ (post oral phase). Numbers of the variables in Figure $4 \mathrm{~b}$ correspond to the compounds 835 listed in Table 1. 
836 Table 1. Chromatographic and physicochemical characteristics of the volatile compounds employed in this study.

\begin{tabular}{|c|c|c|c|c|c|c|c|c|c|c|}
\hline $\mathbf{N}^{\mathbf{0}}$ & Compound & $\begin{array}{c}\text { RI } \\
\exp ^{\mathrm{a}}\end{array}$ & $\begin{array}{c}\text { RI } \\
\text { lit }^{\mathbf{b}}\end{array}$ & $\begin{array}{c}\operatorname{Ion} Q^{c} \\
(\mathbf{m} / \mathbf{z})\end{array}$ & $\begin{array}{c}\mathbf{M W}^{\mathrm{d}} \\
(\mathrm{g} / \mathrm{mol})\end{array}$ & $\underset{\mathrm{e}}{\log P}$ & $\begin{array}{l}\mathbf{B P}^{\mathbf{f}} \\
\left({ }^{\circ} \mathrm{C}\right)\end{array}$ & DESCRIPTOR $^{\mathrm{g}}$ & $\begin{array}{c}\text { CAS } \\
\text { number }\end{array}$ & $\begin{array}{c}\text { Concentration }^{\mathrm{h}}(\mathrm{mg} / \\
\text { L) }\end{array}$ \\
\hline 1 & Ethyl Propanoate & $<1000$ & 950 & 57 & 102 & 1.2 & 99.1 & fruit & $105-37-3$ & 0.61 \\
\hline 2 & Isobutyl acetate & 1018 & 1018 & 56 & 116 & 1.8 & 116.5 & fruit, apple, banana & $110-19-0$ & 0.33 \\
\hline 3 & $\alpha$-pinene & 1030 & 1035 & 93 & 136 & 4.8 & 156.0 & pine, turpentine & $80-56-8$ & 0.20 \\
\hline 4 & Ethyl butanoate & 1043 & 1040 & 71 & 116 & 1.9 & 121.5 & apple & $105-54-4$ & 0.54 \\
\hline 5 & Ethyl 2-methylbutanoate & 1060 & 1056 & 57 & 130 & 2.3 & 133.0 & apple & $7452-79-1$ & 0.29 \\
\hline 6 & Butyl acetate & 1079 & 1079 & 43 & 116 & 1.8 & 126.1 & pear & $123-86-4$ & 0.35 \\
\hline 7 & Isobutanol & 1100 & 1103 & 74 & 74 & 0.8 & 108.0 & wine, solvent, bitter & $78-83-1$ & 1.38 \\
\hline 8 & $\beta$-pinene & 1120 & 1118 & 93 & 136 & 4.4 & 164.0 & pine, resin, turpentine & $127-91-3$ & 0.25 \\
\hline 9 & Isoamyl acetate & 1131 & 1117 & 70 & 130 & 2.3 & 142.5 & banana & $123-92-2$ & 0.69 \\
\hline 10 & 1-butanol & 1154 & 1145 & 56 & 74 & 0.8 & 117.0 & medicine, fruit & $71-36-3$ & 0.93 \\
\hline 11 & Limonene & 1217 & 1208 & 68 & 136 & 4.8 & 176.0 & lemon, orange, citrus & $5989-27-5$ & 0.23 \\
\hline 12 & Isoamylic alcohols & 1217 & 1208 & 55 & 86 & 1.3 & 128.0 & wine,onion & $123-51-3$ & 30.01 \\
\hline 13 & Ethyl hexanoate & 1247 & 1231 & 88 & 136 & 2.8 & 167.0 & apple peel, fruit & $123-66-0$ & 0.89 \\
\hline 14 & Hexyl acetate & 1286 & 1276 & 56 & 144 & 2.8 & 171.5 & fruit, herb & $142-92-7$ & 0.92 \\
\hline 15 & 1-Hexanol & 1364 & 1362 & 56 & 102 & 2.0 & 156.0 & resin, flower, green & $111-27-3$ & 0.91 \\
\hline 16 & trans-3-Hexen-1-ol & 1376 & 1386 & 67 & 100 & 1.6 & 156.5 & mosss, fresh & $928-97-2$ & 0.31 \\
\hline 17 & cis-3-Hexen-1-ol & 1399 & 1398 & 67 & 100 & 1.6 & 156.5 & grass & $928-96-1$ & 0.33 \\
\hline 18 & Ethyl octanoate & 1453 & 1444 & 127 & 172 & 3.8 & 208.5 & fruit, fat & $106-32-1$ & 0.79 \\
\hline 19 & Furfural & 1487 & 1466 & 95 & 96 & 0.4 & 161.7 & bread, almond, sweet & $98-01-1$ & 0.85 \\
\hline 20 & Linalool & 1557 & 1544 & 93 & 154 & 3.0 & 198.0 & flower, lavender & $78-70-6$ & 0.24 \\
\hline 21 & 5-Methylfurfural & 1603 & 1573 & $109+110$ & 110 & 0.7 & 187.0 & almond, caramel, burnt & $620-02-0$ & 0.54 \\
\hline 22 & Terpinen-4-ol & 1633 & 1606 & 93 & 154 & 3.3 & 209.0 & $\begin{array}{c}\text { turpentine, nutmeg, } \\
\text { must }\end{array}$ & $2438-10-0$ & 0.30 \\
\hline 23 & Ethyl decanoate & 1658 & 1636 & 101 & 200 & 4.8 & 241.5 & grape & $110-38-3$ & 0.38 \\
\hline \multirow[t]{2}{*}{24} & Furfuryl alcohol & 1677 & 1672 & 98 & 98 & 0.3 & 171.0 & burnt & $98-00-0$ & 0.55 \\
\hline & & & & & & 34 & & & & \\
\hline
\end{tabular}




\begin{tabular}{|c|c|c|c|c|c|c|c|c|c|c|}
\hline 25 & $\gamma$-butyrolactone & 1674 & 1647 & 42 & 86 & -0.6 & 204.0 & caramel, sweet & $96-48-0$ & 1.97 \\
\hline 26 & Diethyl succinate & 1693 & 1647 & 101 & 174 & 1.2 & 217.7 & wine, fruit & $123-25-1$ & 0.69 \\
\hline 27 & $\alpha$-Terpineol & 1725 & 1688 & 59 & 154 & 3.0 & 217.5 & oil, anise, mint & $10482-56-1$ & 0.20 \\
\hline 28 & $\beta$-Citronellol & 1780 & 1768 & 69 & 156 & 3.9 & 224.0 & rose & $106-22-9$ & 0.28 \\
\hline 29 & Nerol & 1820 & 1792 & 69 & 154 & 3.6 & 225.0 & sweet & $106-25-2$ & 0.23 \\
\hline 30 & $\beta$-phenylethyl acetate & 1852 & 1829 & 104 & 164 & 2.3 & 232.6 & rose, honey, tobacco & $103-45-7$ & 0.74 \\
\hline 31 & Ethyl dodecanoate & 1860 & 1842 & 88 & 228 & 5.7 & 281.2 & leaf & $106-33-2$ & 0.43 \\
\hline 32 & $\beta$-Damascenone & 1860 & 1815 & 190 & 190 & 4.2 & 275.0 & apple, rose, honey & $23726-93-4$ & 0.20 \\
\hline 33 & $\alpha$-ionone & 1894 & 1840 & 93 & 192 & 3.9 & 259.5 & wood, violet & $127-41-3$ & 0.10 \\
\hline 34 & Hexanoic acid & 1900 & 1829 & 60 & 116 & 2.1 & 203.0 & sweat & $142-62-1$ & 0.83 \\
\hline 35 & Benzyl alcohol & 1909 & 1897 & 79 & 108 & 1.1 & 205.3 & sweet, flower & $100-51-6$ & 0.74 \\
\hline 36 & trans-whiskey lactone & 1935 & 1977 & 99 & 156 & 2.0 & 260.6 & flower, lactone & $80041-01-6$ & 0.69 \\
\hline 37 & $\beta$-phenylethyl alcohol & 1948 & 1925 & 91 & 122 & 1.4 & 218.2 & honey, spice, rose, lilac & $60-12-8$ & 3.28 \\
\hline 38 & $\beta$-ionone & 1985 & 1912 & 177 & 192 & 3.8 & 262.9 & $\begin{array}{l}\text { raspberry, violet, } \\
\text { flower, }\end{array}$ & $79-77-6$ & 0.10 \\
\hline 39 & cis-whiskey lactone & 2010 & 1985 & 99 & 156 & 2.0 & 260.6 & coconut & $80041-00-5$ & 0.69 \\
\hline 40 & 4-ethylguaicol & 2067 & 2031 & 137 & 152 & 2.4 & 248.39 & spice, clove & $2785-89-9$ & 0.35 \\
\hline 41 & $\gamma$-Nonalactone & 2081 & 2042 & $85^{*}$ & 156 & 2.1 & 243.0 & coconut, peach & $104-61-0$ & 0.17 \\
\hline 42 & Octanoic acid & 2107 & 2083 & 60 & 144 & 3.1 & 239.0 & sweat, cheese & $124-07-2$ & 1.96 \\
\hline 43 & Eugenol & 2205 & 2164 & $164 *$ & 164 & 2.3 & 253.2 & clove, honey & $97-53-0$ & 0.21 \\
\hline 44 & 4-Ethylphenol & 2205 & 2170 & $107 *$ & 122 & 2.6 & 217.9 & must & $123-07-9$ & 0.40 \\
\hline 45 & Decanoic acid & 2328 & 2361 & 60 & 172 & 4.1 & 278.6 & rancid, fat & $334-48-5$ & 0.78 \\
\hline
\end{tabular}


846 Table 2. Chemical composition of the red and white wines employed in this study.

\begin{tabular}{lcccc}
\hline & \multicolumn{2}{c}{ White Wine } & \multicolumn{2}{c}{ Red Wine } \\
& Mean & SD & Mean & SD \\
\hline Non-volatile residue (\% w/w) & 2.17 & 0.11 & 2.99 & 0.08 \\
pH & 3.23 & 0.01 & 3.79 & 0.01 \\
Total acidity (mg tartaric acid/L) & 5.66 & 0.1 & 4.29 & 0.2 \\
Total polyphenols (mg gallic acid/L) & 269.95 & 17.2 & 1647.98 & 292.8 \\
Neutral polysaccharides (g mannose/L) & 1.67 & 0.5 & 2.50 & 0.9 \\
Residual sugars (g/L) & 1.12 & 0.2 & 3.68 & 0.5 \\
Total nitrogen (mg/L) & 239.96 & 32.9 & 406.00 & 65.7 \\
Amino acids + peptides (mg N/L) & 49.54 & 2.2 & 133.51 & 10.9 \\
Amino acids (mg N/L) & 30.67 & 0.8 & 58.57 & 1.4 \\
Peptides (mg N/L) & 18.87 & - & 79.94 & - \\
\hline
\end{tabular}

847

848 Values are average of two determinations except for $\mathrm{pH}$ (average of three determinations).* This value is indirectly 849 determined as the difference between the analytical determination of amino acids plus peptides and free amino 850 acids, therefore SD (Standard deviation) values are not included in the table. 
851 Table 3. Average aroma release values and results of LSD test in the wines determined by static HS-SPME-GC/MS.

\begin{tabular}{|c|c|c|c|c|c|c|c|c|c|}
\hline & \multicolumn{3}{|c|}{ Synthetic wine } & \multicolumn{3}{|c|}{ White wine } & \multicolumn{3}{|c|}{ Red wine } \\
\hline & Water & $\begin{array}{c}\text { Artificial } \\
\text { saliva }\end{array}$ & $\begin{array}{c}\text { Human } \\
\text { saliva }\end{array}$ & Water & $\begin{array}{c}\text { Artificial } \\
\text { saliva }\end{array}$ & $\begin{array}{c}\text { Human } \\
\text { saliva }\end{array}$ & Water & $\begin{array}{c}\text { Artificial } \\
\text { saliva }\end{array}$ & $\begin{array}{c}\text { Human } \\
\text { saliva }\end{array}$ \\
\hline \multicolumn{10}{|l|}{ Terpenes } \\
\hline$\alpha$-pinene & $495.6 \mathrm{~b}$ & $398.4 \mathrm{a}$ & $412.7 \mathrm{a}$ & $466.3 \mathrm{~b}$ & $392.7 \mathrm{a}$ & $381.6 \mathrm{a}$ & $560.3 \mathrm{c}$ & $442.8 \mathrm{a}$ & $517.5 \mathrm{~b}$ \\
\hline$\beta$-pinene & $584.8 \mathrm{~b}$ & $483.3 \mathrm{a}$ & $488.4 \mathrm{a}$ & $536.5 \mathrm{~b}$ & $461.1 \mathrm{a}$ & $432.7 \mathrm{a}$ & $648.0 \mathrm{c}$ & $533.0 \mathrm{a}$ & $574.1 \mathrm{~b}$ \\
\hline Limonene & $95.1 \mathrm{~b}$ & $76.5 \mathrm{a}$ & $77.9 \mathrm{a}$ & $89.0 \mathrm{~b}$ & $72.8 \mathrm{a}$ & $72.1 \mathrm{a}$ & $99.5 \mathrm{~b}$ & $82.9 \mathrm{a}$ & $82.5 \mathrm{a}$ \\
\hline Linalool & $2.3 \mathrm{a}$ & $2.1 \mathrm{a}$ & $2.2 \mathrm{a}$ & $2.2 \mathrm{a}$ & $2.1 \mathrm{a}$ & $2.1 \mathrm{a}$ & $2.4 \mathrm{~b}$ & $2.4 \mathrm{ab}$ & $2.2 \mathrm{a}$ \\
\hline Terpinen-4-ol & $1.8 \mathrm{a}$ & $1.6 \mathrm{a}$ & $1.6 \mathrm{a}$ & $1.7 \mathrm{a}$ & $1.6 \mathrm{a}$ & $1.7 \mathrm{a}$ & $1.8 \mathrm{~b}$ & $1.7 \mathrm{ab}$ & $1.6 \mathrm{a}$ \\
\hline$\alpha$-terpineol & $1.2 \mathrm{~b}$ & $1.0 \mathrm{a}$ & $1.0 \mathrm{ab}$ & $1.2 \mathrm{~b}$ & $1.1 \mathrm{a}$ & $1.2 \mathrm{~b}$ & $1.2 \mathrm{~b}$ & $1.0 \mathrm{a}$ & $1.0 \mathrm{a}$ \\
\hline$\beta$-citronellol & $2.3 \mathrm{~b}$ & $2.0 \mathrm{a}$ & $2.0 \mathrm{a}$ & $2.1 \mathrm{a}$ & $2.0 \mathrm{a}$ & $2.0 \mathrm{a}$ & $2.3 \mathrm{~b}$ & $2.1 \mathrm{ab}$ & $2.0 \mathrm{a}$ \\
\hline Nerol (cis-geraniol) & $1.7 \mathrm{~b}$ & $1.5 \mathrm{a}$ & $1.5 \mathrm{ab}$ & $1.6 \mathrm{~b}$ & $1.5 \mathrm{a}$ & $1.4 \mathrm{a}$ & $1.7 \mathrm{~b}$ & $1.6 \mathrm{ab}$ & $1.5 \mathrm{a}$ \\
\hline \multicolumn{10}{|l|}{ Esters } \\
\hline Ethyl propanoate & $19.1 \mathrm{~b}$ & $17.9 \mathrm{a}$ & $19.0 \mathrm{~b}$ & $17.9 \mathrm{a}$ & $17.6 \mathrm{a}$ & $17.2 \mathrm{a}$ & $20.1 \mathrm{a}$ & $18.9 \mathrm{a}$ & $18.4 \mathrm{a}$ \\
\hline Isobutyl acetate & $11.8 \mathrm{~b}$ & $11.0 \mathrm{a}$ & $11.6 \mathrm{~b}$ & $10.8 \mathrm{a}$ & $10.9 \mathrm{a}$ & $10.5 \mathrm{a}$ & $12.2 \mathrm{a}$ & $11.4 \mathrm{a}$ & $11.2 \mathrm{a}$ \\
\hline Ethyl butanoate & $39.1 \mathrm{ab}$ & $38.2 \mathrm{a}$ & $41.4 \mathrm{~b}$ & $35.9 \mathrm{a}$ & $36.1 \mathrm{a}$ & $38.0 \mathrm{a}$ & $41.9 \mathrm{~b}$ & $38.1 \mathrm{a}$ & $36.9 \mathrm{a}$ \\
\hline Ethyl 2-methylbutanoate & $29.4 \mathrm{c}$ & $26.6 \mathrm{a}$ & $27.7 \mathrm{~b}$ & $26.4 \mathrm{a}$ & $25.5 \mathrm{a}$ & $25.4 \mathrm{a}$ & $30.4 \mathrm{~b}$ & $27.9 \mathrm{ab}$ & $27.5 \mathrm{a}$ \\
\hline Butyl acetate & $33.6 \mathrm{a}$ & $31.7 \mathrm{a}$ & $27.0 \mathrm{a}$ & $31.6 \mathrm{a}$ & $30.8 \mathrm{a}$ & $31.0 \mathrm{a}$ & $36.5 \mathrm{~b}$ & $34.1 \mathrm{a}$ & $32.8 \mathrm{a}$ \\
\hline Isoamyl acetate & $78.9 \mathrm{c}$ & $71.3 \mathrm{a}$ & $74.5 \mathrm{~b}$ & $72.9 \mathrm{a}$ & $71.2 \mathrm{a}$ & $70.1 \mathrm{a}$ & $82.7 \mathrm{~b}$ & $74.5 \mathrm{a}$ & $73.5 \mathrm{a}$ \\
\hline Ethyl hexanoate & $194.5 \mathrm{~b}$ & $173.2 \mathrm{a}$ & $179.0 \mathrm{a}$ & $179.9 \mathrm{~b}$ & 169.7 a & $170.6 \mathrm{a}$ & $201.4 \mathrm{~b}$ & 183.7 a & $176.6 \mathrm{a}$ \\
\hline Hexyl acetate & $116.9 \mathrm{~b}$ & $104.7 \mathrm{a}$ & 106.8 a & $107.7 \mathrm{~b}$ & $102.3 \mathrm{a}$ & $102.7 \mathrm{a}$ & $121.3 \mathrm{~b}$ & $111.1 \mathrm{a}$ & $106.1 \mathrm{a}$ \\
\hline Ethyl octanoate & $101.0 \mathrm{~b}$ & $83.8 \mathrm{a}$ & $85.8 \mathrm{a}$ & $88.5 \mathrm{~b}$ & $82.1 \mathrm{a}$ & $82.3 \mathrm{a}$ & $95.0 \mathrm{~b}$ & $87.5 \mathrm{a}$ & $82.5 \mathrm{a}$ \\
\hline Ethyl decanoate & $122.2 \mathrm{~b}$ & $96.5 \mathrm{a}$ & $102.0 \mathrm{a}$ & $104.1 \mathrm{~b}$ & $93.4 \mathrm{a}$ & $93.0 \mathrm{a}$ & $102.8 \mathrm{~b}$ & $106.5 \mathrm{~b}$ & $93.8 \mathrm{a}$ \\
\hline Diethyl succinate & $1.6 \mathrm{a}$ & $1.4 \mathrm{a}$ & $1.5 \mathrm{a}$ & $2.2 \mathrm{~b}$ & $2.0 \mathrm{a}$ & $2.1 \mathrm{ab}$ & $2.9 \mathrm{~b}$ & $3.4 \mathrm{c}$ & $1.7 \mathrm{a}$ \\
\hline Beta-phenylethyl acetate & $13.4 \mathrm{~b}$ & $12.2 \mathrm{a}$ & $12.5 \mathrm{ab}$ & $12.8 \mathrm{a}$ & $12.4 \mathrm{a}$ & $12.6 \mathrm{a}$ & $13.6 \mathrm{~b}$ & $12.7 \mathrm{ab}$ & $12.1 \mathrm{a}$ \\
\hline Ethyl dodecanoate & $294.3 \mathrm{~b}$ & $216.3 \mathrm{a}$ & $212.4 \mathrm{a}$ & $215.8 \mathrm{~b}$ & $187.4 \mathrm{a}$ & $182.4 \mathrm{a}$ & $218.5 \mathrm{~b}$ & $243.5 \mathrm{c}$ & $163.3 \mathrm{a}$ \\
\hline \multicolumn{10}{|l|}{ Alcohols } \\
\hline Isobutanol & $0.1 \mathrm{a}$ & $0.1 \mathrm{a}$ & $0.1 \mathrm{a}$ & $0.1 \mathrm{a}$ & $0.1 \mathrm{a}$ & $0.1 \mathrm{a}$ & $0.3 \mathrm{~b}$ & $0.3 \mathrm{~b}$ & $0.2 \mathrm{a}$ \\
\hline
\end{tabular}




\begin{tabular}{|c|c|c|c|c|c|c|c|c|c|}
\hline 1-butanol & $1.0 \mathrm{a}$ & $1.0 \mathrm{a}$ & $1.0 \mathrm{a}$ & $1.0 \mathrm{a}$ & $1.0 \mathrm{a}$ & $1.0 \mathrm{a}$ & $1.2 \mathrm{c}$ & $1.1 \mathrm{~b}$ & $1.0 \mathrm{a}$ \\
\hline Isoamylic alcohols & $53.4 \mathrm{a}$ & $52.1 \mathrm{a}$ & $56.1 \mathrm{a}$ & $52.7 \mathrm{a}$ & $52.1 \mathrm{a}$ & $51.1 \mathrm{a}$ & $59.8 \mathrm{~b}$ & $58.1 \mathrm{~b}$ & $54.0 \mathrm{a}$ \\
\hline 1-hexanol & $8.4 \mathrm{a}$ & $8.1 \mathrm{a}$ & $8.2 \mathrm{a}$ & $8.1 \mathrm{a}$ & $8.1 \mathrm{a}$ & $8.0 \mathrm{a}$ & $9.2 \mathrm{~b}$ & $8.6 \mathrm{a}$ & $8.2 \mathrm{a}$ \\
\hline trans-3-hexen-1-ol & $1.0 \mathrm{a}$ & $0.9 \mathrm{a}$ & $1.0 \mathrm{a}$ & $1.0 \mathrm{a}$ & $0.9 \mathrm{a}$ & $1.0 \mathrm{a}$ & $1.1 \mathrm{~b}$ & $1.0 \mathrm{ab}$ & $1.0 \mathrm{a}$ \\
\hline cis-3-hexen-1-ol & $1.1 \mathrm{a}$ & $1.0 \mathrm{a}$ & $1.0 \mathrm{a}$ & $1.0 \mathrm{a}$ & $1.0 \mathrm{a}$ & $1.0 \mathrm{a}$ & $1.1 \mathrm{~b}$ & $1.1 \mathrm{ab}$ & $1.0 \mathrm{a}$ \\
\hline Benzyl alcohol & $0.4 \mathrm{a}$ & $0.3 \mathrm{a}$ & $0.4 \mathrm{a}$ & $0.4 \mathrm{a}$ & $0.3 \mathrm{a}$ & $0.4 \mathrm{a}$ & $0.4 \mathrm{a}$ & $0.4 \mathrm{a}$ & $0.4 \mathrm{a}$ \\
\hline$\beta$-phenylethyl alcohol & $3.8 \mathrm{a}$ & $3.1 \mathrm{a}$ & $3.6 \mathrm{a}$ & $3.4 \mathrm{a}$ & $2.9 \mathrm{a}$ & $3.0 \mathrm{a}$ & $3.7 \mathrm{a}$ & $4.0 \mathrm{a}$ & $3.4 \mathrm{a}$ \\
\hline \multicolumn{10}{|l|}{ Lactones/Furanic } \\
\hline Furfural & $3.0 \mathrm{~b}$ & $2.7 \mathrm{a}$ & $2.9 \mathrm{~b}$ & $2.7 \mathrm{~b}$ & $2.6 \mathrm{a}$ & $2.7 \mathrm{ab}$ & $3.0 \mathrm{~b}$ & $2.8 \mathrm{~b}$ & $2.7 \mathrm{a}$ \\
\hline 5- methylfurfural & $1.3 \mathrm{~b}$ & $1.1 \mathrm{a}$ & $1.2 \mathrm{ab}$ & $1.2 \mathrm{a}$ & $1.1 \mathrm{a}$ & $1.2 \mathrm{a}$ & $1.3 \mathrm{~b}$ & $1.2 \mathrm{~b}$ & $1.2 \mathrm{a}$ \\
\hline$\gamma$-butyrolactone & $0.2 \mathrm{a}$ & $0.2 \mathrm{a}$ & $0.2 \mathrm{a}$ & $0.3 \mathrm{~b}$ & $0.2 \mathrm{a}$ & $0.2 \mathrm{ab}$ & $0.4 \mathrm{a}$ & $0.5 \mathrm{a}$ & $0.4 \mathrm{a}$ \\
\hline Furfuryl alcohol & $0.2 \mathrm{a}$ & $0.2 \mathrm{a}$ & $0.2 \mathrm{a}$ & $0.2 \mathrm{a}$ & $0.2 \mathrm{a}$ & $0.2 \mathrm{a}$ & $0.2 \mathrm{a}$ & $0.2 \mathrm{a}$ & $0.2 \mathrm{a}$ \\
\hline trans-whiskey lactone & $0.9 \mathrm{a}$ & $0.8 \mathrm{a}$ & $0.8 \mathrm{a}$ & $0.8 \mathrm{a}$ & $0.8 \mathrm{a}$ & $0.8 \mathrm{a}$ & $0.9 \mathrm{a}$ & $0.9 \mathrm{a}$ & $0.8 \mathrm{a}$ \\
\hline cis-whiskey lactone & $0.7 \mathrm{a}$ & $0.6 \mathrm{a}$ & $0.6 \mathrm{a}$ & $0.6 \mathrm{a}$ & $0.6 \mathrm{a}$ & $0.6 \mathrm{a}$ & $0.7 \mathrm{~b}$ & $0.6 \mathrm{ab}$ & $0.6 \mathrm{a}$ \\
\hline$\gamma$-nonalactone & $0.5 \mathrm{a}$ & $0.4 \mathrm{a}$ & $0.4 \mathrm{a}$ & $0.4 \mathrm{a}$ & $0.3 \mathrm{a}$ & $0.4 \mathrm{a}$ & $0.4 \mathrm{~b}$ & $0.4 \mathrm{~b}$ & $0.3 \mathrm{a}$ \\
\hline \multicolumn{10}{|l|}{ Volatile phenols } \\
\hline 2-methoxy,4-ethylphenol & $1.7 \mathrm{~b}$ & $1.5 \mathrm{a}$ & $1.5 \mathrm{ab}$ & $1.6 \mathrm{a}$ & $1.5 \mathrm{a}$ & $1.6 \mathrm{a}$ & $1.7 \mathrm{~b}$ & $1.6 \mathrm{~b}$ & $1.5 \mathrm{a}$ \\
\hline Eugenol & $0.3 \mathrm{~b}$ & $0.3 \mathrm{a}$ & $0.3 \mathrm{ab}$ & $0.3 \mathrm{a}$ & $0.3 \mathrm{a}$ & $0.3 \mathrm{a}$ & $0.3 \mathrm{~b}$ & $0.3 \mathrm{~b}$ & $0.3 \mathrm{a}$ \\
\hline 4-ethylphenol & $1.3 \mathrm{a}$ & $1.1 \mathrm{a}$ & $1.2 \mathrm{a}$ & $1.2 \mathrm{a}$ & $1.1 \mathrm{a}$ & $1.1 \mathrm{a}$ & $1.3 \mathrm{a}$ & $1.3 \mathrm{a}$ & $1.2 \mathrm{a}$ \\
\hline \multicolumn{10}{|l|}{ C13-norisoprenoids } \\
\hline$\beta$-damascenone & $1.6 \mathrm{a}$ & $1.5 \mathrm{a}$ & $1.6 \mathrm{a}$ & $1.6 \mathrm{a}$ & $1.5 \mathrm{a}$ & $1.5 \mathrm{a}$ & $1.6 \mathrm{~b}$ & $1.5 \mathrm{ab}$ & $1.4 \mathrm{a}$ \\
\hline$\alpha$-ionone & $2.5 \mathrm{a}$ & $2.3 \mathrm{a}$ & $2.3 \mathrm{a}$ & $2.4 \mathrm{~b}$ & $2.2 \mathrm{a}$ & $2.3 \mathrm{a}$ & $2.4 \mathrm{~b}$ & $2.3 \mathrm{~b}$ & $2.2 \mathrm{a}$ \\
\hline$\beta$-ionone & $4.4 \mathrm{~b}$ & $4.0 \mathrm{a}$ & $3.9 \mathrm{a}$ & $4.2 \mathrm{~b}$ & $3.9 \mathrm{a}$ & $4.0 \mathrm{ab}$ & $4.2 \mathrm{~b}$ & $4.0 \mathrm{ab}$ & $3.7 \mathrm{a}$ \\
\hline \multicolumn{10}{|l|}{ Acids } \\
\hline Hexanoic acid & $1.0 \mathrm{~b}$ & $0.8 \mathrm{a}$ & $1.0 \mathrm{~b}$ & $0.9 \mathrm{a}$ & $0.8 \mathrm{a}$ & $0.9 \mathrm{a}$ & $1.1 \mathrm{~b}$ & $0.8 \mathrm{a}$ & $0.9 \mathrm{a}$ \\
\hline Octanoic acid & $2.7 \mathrm{~b}$ & $2.2 \mathrm{a}$ & $2.7 \mathrm{ab}$ & $2.6 \mathrm{~b}$ & $2.4 \mathrm{a}$ & $2.3 \mathrm{a}$ & $2.8 \mathrm{~b}$ & $2.1 \mathrm{a}$ & $2.3 \mathrm{a}$ \\
\hline Decanoic acid & $2.5 \mathrm{~b}$ & $1.3 \mathrm{a}$ & $1.4 \mathrm{a}$ & $1.5 \mathrm{~b}$ & $1.3 \mathrm{ab}$ & $1.2 \mathrm{a}$ & $1.4 \mathrm{~b}$ & $1.1 \mathrm{a}$ & $1.4 \mathrm{~b}$ \\
\hline
\end{tabular}


855 Table 4. Viscosity and $\mathrm{pH}$ values determined for the saliva samples and wine/saliva mixtures $856(n=3)$.

857

\begin{tabular}{|c|c|c|c|c|c|c|}
\hline & \multirow{3}{*}{ WaterMean (SD) } & $\begin{array}{l}\text { Viscosity } \\
(\mathrm{mPa} \times \mathrm{s})\end{array}$ & & & \multicolumn{2}{|r|}{ pH } \\
\hline & & Human saliva & Artificial saliva & Water & $\begin{array}{l}\text { Human } \\
\text { saliva }\end{array}$ & $\begin{array}{c}\text { Artificial salivaMean } \\
\text { (SD) }\end{array}$ \\
\hline & & Mean (SD) & Mean (SD) & $\begin{array}{l}\text { Mean } \\
(\mathrm{SD})\end{array}$ & Mean (SD) & \\
\hline Salivas & - & $7.0(0.1)$ & $7.9(0.2)$ & - & $8.2(0.1)$ & $8.4(0.2)$ \\
\hline Red wine & $7.2(0.1)$ & $7.3(0.1)$ & $7.1(0.1)$ & $3.8(0)$ & $4.0(0.1)$ & $4.2(0.1)$ \\
\hline White wine & $6.9(0.0)$ & $7.3(0.3)$ & $7.4(0.5)$ & $3.1(0)$ & $3.3(0.1)$ & $3.7(0.1)$ \\
\hline
\end{tabular}


Table 5. Average aroma release values and results of LSD test in the wines determined by dynamic HS-SPME-GC/MS at $\mathrm{t}=0$ (oral-phase).

\begin{tabular}{|c|c|c|c|c|c|c|c|c|c|}
\hline & \multicolumn{3}{|c|}{ Synthetic wine } & \multicolumn{3}{|c|}{ White wine } & \multicolumn{3}{|c|}{ Red wine } \\
\hline & Water & $\begin{array}{c}\text { Artificial } \\
\text { saliva }\end{array}$ & $\begin{array}{c}\text { Human } \\
\text { saliva }\end{array}$ & Water & $\begin{array}{c}\text { Artificial } \\
\text { saliva }\end{array}$ & $\begin{array}{l}\text { Human } \\
\text { saliva }\end{array}$ & Water & $\begin{array}{c}\text { Artificial } \\
\text { saliva }\end{array}$ & $\begin{array}{c}\text { Human } \\
\text { saliva }\end{array}$ \\
\hline \multicolumn{10}{|l|}{ Terpenes } \\
\hline$\alpha$-pinene & $49.1 \mathrm{~b}$ & $0.2 \mathrm{a}$ & $19.0 \mathrm{a}$ & $7.2 \mathrm{~b}$ & $2.0 \mathrm{a}$ & $0.7 \mathrm{a}$ & $10.9 \mathrm{c}$ & $1.3 \mathrm{a}$ & $3.7 \mathrm{~b}$ \\
\hline$\beta$-pinene & $45.1 \mathrm{~b}$ & $0.0 \mathrm{a}$ & $16.3 \mathrm{a}$ & $9.9 \mathrm{~b}$ & $3.2 \mathrm{a}$ & $1.1 \mathrm{a}$ & $19.4 \mathrm{c}$ & $3.3 \mathrm{a}$ & $7.3 \mathrm{~b}$ \\
\hline Limonene & $14.8 \mathrm{~b}$ & $0.9 \mathrm{a}$ & $7.1 \mathrm{a}$ & $4.6 \mathrm{~b}$ & $3.4 \mathrm{~b}$ & $1.6 \mathrm{a}$ & $3.9 \mathrm{c}$ & $1.4 \mathrm{a}$ & $2.3 \mathrm{~b}$ \\
\hline Linalool & $1.7 \mathrm{a}$ & $1.6 \mathrm{a}$ & $1.7 \mathrm{a}$ & $1.9 \mathrm{a}$ & $1.9 \mathrm{a}$ & $1.9 \mathrm{a}$ & $1.8 \mathrm{a}$ & $1.6 \mathrm{a}$ & $2.1 \mathrm{~b}$ \\
\hline Terpinen-4-ol & $1.2 \mathrm{a}$ & $1.1 \mathrm{a}$ & $1.1 \mathrm{a}$ & $1.3 \mathrm{a}$ & $1.3 \mathrm{a}$ & $1.3 \mathrm{a}$ & $1.3 \mathrm{ab}$ & $1.1 \mathrm{a}$ & $1.5 \mathrm{~b}$ \\
\hline$\alpha$-terpineol & $1.0 \mathrm{a}$ & $1.1 \mathrm{a}$ & $0.9 \mathrm{a}$ & $0.7 \mathrm{a}$ & $0.8 \mathrm{a}$ & $0.8 \mathrm{a}$ & $0.7 \mathrm{a}$ & $0.6 \mathrm{a}$ & $0.9 \mathrm{~b}$ \\
\hline$\beta$-citronellol & $1.4 \mathrm{a}$ & $1.1 \mathrm{a}$ & $1.1 \mathrm{a}$ & $1.3 \mathrm{a}$ & $1.4 \mathrm{a}$ & $1.3 \mathrm{a}$ & $1.3 \mathrm{~b}$ & $1.1 \mathrm{a}$ & $1.6 \mathrm{c}$ \\
\hline Nerol (cis-geraniol) & $0.9 \mathrm{~b}$ & $0.7 \mathrm{a}$ & $0.8 \mathrm{ab}$ & $0.9 \mathrm{a}$ & $0.9 \mathrm{a}$ & $0.9 \mathrm{a}$ & $0.9 \mathrm{ab}$ & $0.8 \mathrm{a}$ & $1.1 \mathrm{~b}$ \\
\hline \multicolumn{10}{|l|}{ Esters } \\
\hline Ethyl propanoate & $37.8 \mathrm{a}$ & $36.1 \mathrm{a}$ & $39.7 \mathrm{~b}$ & $39.1 \mathrm{a}$ & $41.8 \mathrm{a}$ & $41.2 \mathrm{a}$ & $38.6 \mathrm{~b}$ & $37.1 \mathrm{a}$ & $36.8 \mathrm{a}$ \\
\hline Isobutyl acetate & $19.2 \mathrm{~b}$ & $16.8 \mathrm{a}$ & $18.9 \mathrm{~b}$ & $19.0 \mathrm{a}$ & $20.0 \mathrm{a}$ & $19.2 \mathrm{a}$ & $18.5 \mathrm{c}$ & $17.2 \mathrm{a}$ & $17.8 \mathrm{~b}$ \\
\hline Ethyl butanoate & $58.9 \mathrm{~b}$ & $52.0 \mathrm{a}$ & $60.6 \mathrm{~b}$ & $58.5 \mathrm{a}$ & $63.0 \mathrm{a}$ & $58.2 \mathrm{a}$ & $57.5 \mathrm{c}$ & $53.5 \mathrm{a}$ & $55.5 \mathrm{~b}$ \\
\hline Ethyl 2-methylbutanoate & $34.8 \mathrm{~b}$ & $28.7 \mathrm{a}$ & $32.1 \mathrm{ab}$ & $32.3 \mathrm{a}$ & $34.4 \mathrm{a}$ & $32.0 \mathrm{a}$ & $31.3 \mathrm{c}$ & $28.8 \mathrm{a}$ & $30.2 \mathrm{~b}$ \\
\hline Butyl acetate & $48.0 \mathrm{a}$ & $45.9 \mathrm{a}$ & $48.4 \mathrm{a}$ & $48.6 \mathrm{a}$ & $51.6 \mathrm{a}$ & $50.3 \mathrm{a}$ & $47.8 \mathrm{a}$ & $43.6 \mathrm{a}$ & $47.6 \mathrm{a}$ \\
\hline Isoamyl acetate & $100.1 \mathrm{~b}$ & $89.2 \mathrm{a}$ & $96.6 \mathrm{ab}$ & $94.7 \mathrm{a}$ & $104.4 \mathrm{a}$ & $88.8 \mathrm{a}$ & $94.1 \mathrm{a}$ & $82.9 \mathrm{a}$ & $94.1 \mathrm{a}$ \\
\hline Ethyl hexanoate & $184.0 \mathrm{~b}$ & $150.7 \mathrm{a}$ & 164.7 & $169.9 \mathrm{a}$ & $176.4 \mathrm{a}$ & $164.3 \mathrm{a}$ & $151.0 \mathrm{a}$ & $136.4 \mathrm{a}$ & $153.7 \mathrm{a}$ \\
\hline Hexyl acetate & $112.4 \mathrm{~b}$ & $93.1 \mathrm{a}$ & 101.1 & 104.7 a & $108.3 \mathrm{a}$ & $101.7 \mathrm{a}$ & $91.8 \mathrm{a}$ & $82.6 \mathrm{a}$ & $93.6 \mathrm{a}$ \\
\hline Ethyl octanoate & $65.9 \mathrm{~b}$ & $46.6 \mathrm{a}$ & $50.1 \mathrm{a}$ & $56.5 \mathrm{a}$ & $59.7 \mathrm{a}$ & $53.3 \mathrm{a}$ & $42.2 \mathrm{ab}$ & $38.2 \mathrm{a}$ & $43.5 \mathrm{~b}$ \\
\hline Ethyl decanoate & $35.4 \mathrm{~b}$ & $19.5 \mathrm{a}$ & $19.3 \mathrm{a}$ & $25.0 \mathrm{a}$ & $26.4 \mathrm{a}$ & $22.2 \mathrm{a}$ & $17.8 \mathrm{a}$ & $15.3 \mathrm{a}$ & $17.8 \mathrm{a}$ \\
\hline Diethyl succinate & $1.0 \mathrm{a}$ & $0.9 \mathrm{a}$ & $0.9 \mathrm{a}$ & $1.1 \mathrm{a}$ & $1.2 \mathrm{a}$ & $1.1 \mathrm{a}$ & $1.8 \mathrm{a}$ & $1.9 \mathrm{a}$ & $2.5 \mathrm{~b}$ \\
\hline Beta-phenylethyl acetate & $11.5 \mathrm{a}$ & $11.6 \mathrm{a}$ & $11.0 \mathrm{a}$ & $13.3 \mathrm{a}$ & $13.9 \mathrm{a}$ & $13.7 \mathrm{a}$ & $12.7 \mathrm{ab}$ & $11.8 \mathrm{a}$ & $14.9 \mathrm{~b}$ \\
\hline Ethyl dodecanoate & $29.2 \mathrm{a}$ & $14.0 \mathrm{a}$ & $11.8 \mathrm{a}$ & $13.0 \mathrm{a}$ & $14.3 \mathrm{a}$ & $11.2 \mathrm{a}$ & $9.9 \mathrm{c}$ & $6.1 \mathrm{a}$ & $7.9 \mathrm{~b}$ \\
\hline \multicolumn{10}{|l|}{ Alcohols } \\
\hline \multirow[t]{2}{*}{ Isobutanol } & $0.2 \mathrm{a}$ & $0.3 \mathrm{a}$ & $0.4 \mathrm{a}$ & $0.3 \mathrm{a}$ & $0.3 \mathrm{a}$ & $0.3 \mathrm{a}$ & $0.5 \mathrm{a}$ & $0.5 \mathrm{a}$ & $0.5 \mathrm{a}$ \\
\hline & & & & & 40 & & & & \\
\hline
\end{tabular}




\begin{tabular}{|c|c|c|c|c|c|c|c|c|c|}
\hline 1-butanol & $1.6 \mathrm{a}$ & $1.6 \mathrm{a}$ & $2.0 \mathrm{a}$ & $1.7 \mathrm{a}$ & $1.7 \mathrm{a}$ & $1.7 \mathrm{a}$ & $1.8 \mathrm{a}$ & $1.7 \mathrm{a}$ & $1.9 \mathrm{a}$ \\
\hline Isoamylic alcohols & $68.0 \mathrm{a}$ & $77.3 \mathrm{~b}$ & $75.9 \mathrm{~b}$ & $78.7 \mathrm{a}$ & $80.7 \mathrm{a}$ & $79.6 \mathrm{a}$ & $83.0 \mathrm{a}$ & $78.4 \mathrm{a}$ & $85.3 \mathrm{a}$ \\
\hline 1-hexanol & $9.2 \mathrm{a}$ & $9.9 \mathrm{a}$ & $9.9 \mathrm{a}$ & $10.4 \mathrm{a}$ & $10.6 \mathrm{a}$ & $10.7 \mathrm{a}$ & $10.7 \mathrm{a}$ & $9.7 \mathrm{a}$ & $11.3 \mathrm{a}$ \\
\hline trans-3-hexen-1-ol & $1.1 \mathrm{a}$ & $1.1 \mathrm{a}$ & $1.2 \mathrm{a}$ & $1.1 \mathrm{a}$ & $1.2 \mathrm{a}$ & $1.2 \mathrm{a}$ & $1.2 \mathrm{ab}$ & $1.1 \mathrm{a}$ & $1.3 \mathrm{~b}$ \\
\hline cis-3-hexen-1-ol & $0.9 \mathrm{a}$ & $0.9 \mathrm{a}$ & $1.1 \mathrm{~b}$ & $1.0 \mathrm{a}$ & $1.0 \mathrm{a}$ & $0.9 \mathrm{a}$ & $1.0 \mathrm{ab}$ & $0.9 \mathrm{a}$ & $1.2 \mathrm{~b}$ \\
\hline Benzyl alcohol & $0.2 \mathrm{a}$ & $0.2 \mathrm{a}$ & $0.3 \mathrm{a}$ & $0.3 \mathrm{a}$ & $0.3 \mathrm{a}$ & $0.3 \mathrm{a}$ & $0.3 \mathrm{a}$ & $0.3 \mathrm{a}$ & $0.4 \mathrm{~b}$ \\
\hline$\beta$-phenylethyl alcohol & $1.9 \mathrm{a}$ & $1.9 \mathrm{a}$ & $1.9 \mathrm{a}$ & $2.1 \mathrm{a}$ & $2.6 \mathrm{a}$ & $2.5 \mathrm{a}$ & $2.1 \mathrm{a}$ & $2.3 \mathrm{a}$ & $3.2 \mathrm{~b}$ \\
\hline \multicolumn{10}{|l|}{ Lactones/Furanic } \\
\hline Furfural & $2.9 \mathrm{a}$ & $2.7 \mathrm{a}$ & $3.2 \mathrm{~b}$ & $2.1 \mathrm{a}$ & $2.3 \mathrm{a}$ & $2.1 \mathrm{a}$ & $2.7 \mathrm{a}$ & $2.6 \mathrm{a}$ & $3.3 \mathrm{~b}$ \\
\hline 5- methylfurfural & $1.2 \mathrm{a}$ & $1.1 \mathrm{a}$ & $1.2 \mathrm{~b}$ & $1.1 \mathrm{a}$ & $1.2 \mathrm{a}$ & $1.2 \mathrm{a}$ & $1.1 \mathrm{a}$ & $1.1 \mathrm{a}$ & $1.4 \mathrm{~b}$ \\
\hline$\gamma$-butyrolactone & $0.3 \mathrm{a}$ & $0.3 \mathrm{a}$ & $0.3 \mathrm{a}$ & $0.3 \mathrm{a}$ & $0.4 \mathrm{a}$ & $0.4 \mathrm{a}$ & $0.5 \mathrm{a}$ & $0.4 \mathrm{a}$ & $0.6 \mathrm{a}$ \\
\hline Furfuryl alcohol & $0.1 \mathrm{a}$ & $0.1 \mathrm{a}$ & $0.1 \mathrm{~b}$ & $0.1 \mathrm{a}$ & $0.2 \mathrm{a}$ & $0.2 \mathrm{a}$ & $0.1 \mathrm{a}$ & $0.1 \mathrm{a}$ & $0.2 \mathrm{a}$ \\
\hline trans-whiskey lactone & $0.6 \mathrm{a}$ & $0.5 \mathrm{a}$ & $0.5 \mathrm{a}$ & $0.6 \mathrm{a}$ & $0.7 \mathrm{a}$ & $0.6 \mathrm{a}$ & $0.6 \mathrm{a}$ & $0.6 \mathrm{a}$ & $0.8 \mathrm{~b}$ \\
\hline cis-whiskey lactone & $0.4 \mathrm{a}$ & $0.4 \mathrm{a}$ & $0.3 \mathrm{a}$ & $0.4 \mathrm{a}$ & $0.5 \mathrm{a}$ & $0.4 \mathrm{a}$ & $0.4 \mathrm{a}$ & $0.4 \mathrm{a}$ & $0.6 \mathrm{~b}$ \\
\hline$\gamma$-nonalactone & $0.2 \mathrm{a}$ & $0.2 \mathrm{a}$ & $0.2 \mathrm{a}$ & $0.2 \mathrm{a}$ & $0.3 \mathrm{~b}$ & $0.3 \mathrm{~b}$ & $0.3 \mathrm{a}$ & $0.2 \mathrm{a}$ & $0.3 \mathrm{~b}$ \\
\hline \multicolumn{10}{|l|}{ Volatile phenols } \\
\hline 2-methoxy,4-ethylphenol & $1.0 \mathrm{a}$ & $1.0 \mathrm{a}$ & $0.9 \mathrm{a}$ & $1.1 \mathrm{a}$ & $1.2 \mathrm{a}$ & $1.2 \mathrm{a}$ & $1.1 \mathrm{a}$ & $1.1 \mathrm{a}$ & $1.4 \mathrm{a}$ \\
\hline Eugenol & $0.1 \mathrm{a}$ & $0.2 \mathrm{a}$ & $0.1 \mathrm{a}$ & $0.2 \mathrm{a}$ & $0.2 \mathrm{~b}$ & $0.2 \mathrm{~b}$ & $0.1 \mathrm{a}$ & $0.2 \mathrm{ab}$ & $0.2 \mathrm{~b}$ \\
\hline 4-ethylphenol & $0.7 \mathrm{a}$ & $0.7 \mathrm{a}$ & $0.6 \mathrm{a}$ & $0.8 \mathrm{a}$ & $0.9 \mathrm{a}$ & $0.9 \mathrm{a}$ & $0.7 \mathrm{a}$ & $0.8 \mathrm{a}$ & $1.1 \mathrm{~b}$ \\
\hline \multicolumn{10}{|l|}{ C13-norisoprenoids } \\
\hline$\beta$-damascenone & $1.2 \mathrm{a}$ & $1.2 \mathrm{a}$ & $1.1 \mathrm{a}$ & $1.4 \mathrm{a}$ & $1.4 \mathrm{a}$ & 1.4 & $1.3 \mathrm{ab}$ & $1.1 \mathrm{a}$ & $1.5 \mathrm{~b}$ \\
\hline$\alpha$-ionone & $1.9 \mathrm{a}$ & $1.6 \mathrm{a}$ & $1.5 \mathrm{a}$ & $2.0 \mathrm{a}$ & $2.0 \mathrm{a}$ & 1.9 & $1.8 \mathrm{ab}$ & $1.5 \mathrm{a}$ & $2.1 \mathrm{~b}$ \\
\hline$\beta$-ionone & $2.9 \mathrm{~b}$ & $2.5 \mathrm{ab}$ & $2.2 \mathrm{a}$ & $3.1 \mathrm{a}$ & $3.1 \mathrm{a}$ & 3.1 & $2.8 \mathrm{a}$ & $2.5 \mathrm{a}$ & $3.4 \mathrm{~b}$ \\
\hline \multicolumn{10}{|l|}{ Acids } \\
\hline Hexanoic acid & $0.6 \mathrm{~b}$ & $0.5 \mathrm{a}$ & $0.7 \mathrm{~b}$ & $0.8 \mathrm{a}$ & $0.8 \mathrm{a}$ & 0.7 & $0.3 \mathrm{a}$ & $0.5 \mathrm{a}$ & $0.9 \mathrm{a}$ \\
\hline Octanoic acid & $1.2 \mathrm{a}$ & $1.1 \mathrm{a}$ & $1.1 \mathrm{a}$ & $1.6 \mathrm{a}$ & $2.2 \mathrm{a}$ & 1.5 & $1.8 \mathrm{a}$ & $1.5 \mathrm{a}$ & $2.0 \mathrm{a}$ \\
\hline Decanoic acid & nd & nd & nd & nd & nd & nd & nd & nd & nd \\
\hline
\end{tabular}

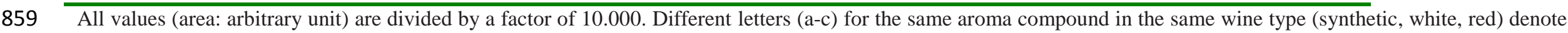
860 statistical differences among saliva types after applying LSD test 
Table 6. Average aroma release values and LSD test in the wines determined by dynamic HS-SPME-GC/MS at $\mathrm{t}=10$ (post oral-phase).

\begin{tabular}{|c|c|c|c|c|c|c|c|c|c|}
\hline & \multicolumn{3}{|c|}{ Synthetic wine } & \multicolumn{3}{|c|}{ White wine } & \multicolumn{3}{|c|}{ Red wine } \\
\hline & Water & $\begin{array}{c}\text { Artificial } \\
\text { saliva }\end{array}$ & $\begin{array}{c}\text { Human } \\
\text { saliva }\end{array}$ & Water & $\begin{array}{c}\text { Artificial } \\
\text { saliva }\end{array}$ & $\begin{array}{c}\text { Human } \\
\text { saliva }\end{array}$ & Water & $\begin{array}{c}\text { Artificial } \\
\text { saliva }\end{array}$ & $\begin{array}{c}\text { Human } \\
\text { saliva }\end{array}$ \\
\hline \multicolumn{10}{|l|}{ Terpenes } \\
\hline$\alpha$-pinene & $20.6 \mathrm{a}$ & $0.2 \mathrm{a}$ & $19.0 \mathrm{a}$ & $6.8 \mathrm{~b}$ & $1.6 \mathrm{a}$ & $0.7 \mathrm{a}$ & $8.8 \mathrm{~b}$ & $1.2 \mathrm{a}$ & $3.7 \mathrm{a}$ \\
\hline$\beta$-pinene & $21.6 \mathrm{a}$ & $0.1 \mathrm{a}$ & $18.4 \mathrm{a}$ & $9.8 \mathrm{~b}$ & $2.8 \mathrm{a}$ & $1.1 \mathrm{a}$ & $17.5 \mathrm{~b}$ & $3.6 \mathrm{a}$ & $7.5 \mathrm{a}$ \\
\hline Limonene & 11.9 & $1.3 \mathrm{a}$ & $9.7 \mathrm{a}$ & $5.5 \mathrm{c}$ & $3.6 \mathrm{~b}$ & $2.2 \mathrm{a}$ & $4.2 \mathrm{c}$ & $1.7 \mathrm{a}$ & $2.7 \mathrm{~b}$ \\
\hline Linalool & $4.4 \mathrm{a}$ & $4.9 \mathrm{a}$ & $4.6 \mathrm{a}$ & $4.5 \mathrm{a}$ & $4.5 \mathrm{a}$ & $5.0 \mathrm{~b}$ & $4.3 \mathrm{a}$ & $4.1 \mathrm{a}$ & $4.3 \mathrm{a}$ \\
\hline Terpinen-4-ol & $3.6 \mathrm{a}$ & $3.8 \mathrm{a}$ & $3.4 \mathrm{a}$ & $3.5 \mathrm{a}$ & $3.5 \mathrm{a}$ & $3.6 \mathrm{a}$ & $3.4 \mathrm{a}$ & $3.2 \mathrm{a}$ & $3.3 \mathrm{a}$ \\
\hline$\alpha$-terpineol & $3.1 \mathrm{a}$ & $3.5 \mathrm{a}$ & $2.9 \mathrm{a}$ & $2.0 \mathrm{a}$ & $2.1 \mathrm{a}$ & $2.3 \mathrm{a}$ & $1.9 \mathrm{a}$ & $1.8 \mathrm{a}$ & $1.8 \mathrm{a}$ \\
\hline$\beta$-citronellol & $4.1 \mathrm{a}$ & $4.0 \mathrm{a}$ & $3.7 \mathrm{a}$ & $3.8 \mathrm{ab}$ & $3.5 \mathrm{a}$ & $4.0 \mathrm{~b}$ & $3.6 \mathrm{a}$ & $3.4 \mathrm{a}$ & $3.5 \mathrm{a}$ \\
\hline Nerol (cis-geraniol) & $2.3 \mathrm{a}$ & $2.3 \mathrm{a}$ & $2.4 \mathrm{a}$ & $2.1 \mathrm{ab}$ & $2.0 \mathrm{a}$ & $2.4 \mathrm{~b}$ & $2.2 \mathrm{a}$ & $2.1 \mathrm{a}$ & $2.2 \mathrm{a}$ \\
\hline \multicolumn{10}{|l|}{ Esters } \\
\hline Ethyl propanoate & $28.7 \mathrm{a}$ & $32.5 \mathrm{~b}$ & $31.1 \mathrm{a}$ & $32.1 \mathrm{a}$ & $32.3 \mathrm{a}$ & $32.3 \mathrm{a}$ & $30.4 \mathrm{a}$ & $28.9 \mathrm{a}$ & $30.2 \mathrm{a}$ \\
\hline Isobutyl acetate & $17.6 \mathrm{a}$ & $19.1 \mathrm{a}$ & $18.5 \mathrm{a}$ & $18.5 \mathrm{a}$ & $19.5 \mathrm{~b}$ & $18.6 \mathrm{a}$ & $17.7 \mathrm{a}$ & $17.0 \mathrm{a}$ & $17.3 \mathrm{a}$ \\
\hline Ethyl butanoate & $61.8 \mathrm{a}$ & $65.2 \mathrm{a}$ & $66.6 \mathrm{a}$ & $64.2 \mathrm{a}$ & $66.3 \mathrm{a}$ & $62.7 \mathrm{a}$ & $60.0 \mathrm{a}$ & $56.2 \mathrm{a}$ & $59.2 \mathrm{a}$ \\
\hline Ethyl 2-methylbutanoate & $35.0 \mathrm{a}$ & $37.9 \mathrm{a}$ & $36.4 \mathrm{a}$ & $35.4 \mathrm{ab}$ & $36.9 \mathrm{~b}$ & $34.8 \mathrm{a}$ & $33.5 \mathrm{~b}$ & $31.9 \mathrm{a}$ & $32.2 \mathrm{ab}$ \\
\hline Butyl acetate & $52.3 \mathrm{a}$ & $59.7 \mathrm{~b}$ & $55.8 \mathrm{a}$ & $55.4 \mathrm{a}$ & $58.3 \mathrm{~b}$ & $56.3 \mathrm{a}$ & $54.1 \mathrm{a}$ & $52.8 \mathrm{a}$ & $52.9 \mathrm{a}$ \\
\hline Isoamyl acetate & 117.5 & $124.9 \mathrm{a}$ & $120.2 \mathrm{a}$ & $118.1 \mathrm{a}$ & $123.0 \mathrm{a}$ & $117.9 \mathrm{a}$ & $110.5 \mathrm{a}$ & $110.6 \mathrm{a}$ & $108.4 \mathrm{a}$ \\
\hline Ethyl hexanoate & 256.6 & $264.6 \mathrm{a}$ & $257.3 \mathrm{a}$ & $242.0 \mathrm{a}$ & $248.2 \mathrm{a}$ & $240.6 \mathrm{a}$ & $216.9 \mathrm{a}$ & $206.5 \mathrm{a}$ & $210.6 \mathrm{a}$ \\
\hline Hexyl acetate & 159.9 & $163.8 \mathrm{a}$ & $159.2 \mathrm{a}$ & $150.4 \mathrm{a}$ & $153.4 \mathrm{a}$ & $149.5 \mathrm{a}$ & $133.3 \mathrm{a}$ & $126.1 \mathrm{a}$ & $128.8 \mathrm{a}$ \\
\hline Ethyl octanoate & 100.9 & $94.7 \mathrm{a}$ & $94.2 \mathrm{a}$ & $84.6 \mathrm{a}$ & $83.5 \mathrm{a}$ & $83.2 \mathrm{a}$ & $63.9 \mathrm{a}$ & $59.5 \mathrm{a}$ & $60.7 \mathrm{a}$ \\
\hline Ethyl decanoate & $57.2 \mathrm{a}$ & $45.8 \mathrm{a}$ & $45.2 \mathrm{a}$ & $45.0 \mathrm{a}$ & $42.1 \mathrm{a}$ & $42.6 \mathrm{a}$ & $31.4 \mathrm{a}$ & $28.2 \mathrm{a}$ & $28.7 \mathrm{a}$ \\
\hline Diethyl succinate & $2.2 \mathrm{a}$ & $2.1 \mathrm{a}$ & $2.1 \mathrm{a}$ & $2.3 \mathrm{a}$ & $2.2 \mathrm{a}$ & $2.4 \mathrm{a}$ & $4.2 \mathrm{a}$ & $3.7 \mathrm{a}$ & $4.0 \mathrm{a}$ \\
\hline Beta-phenylethyl acetate & $25.6 \mathrm{a}$ & $29.5 \mathrm{a}$ & $26.7 \mathrm{a}$ & $28.3 \mathrm{a}$ & $26.6 \mathrm{a}$ & $28.8 \mathrm{a}$ & $26.9 \mathrm{a}$ & $25.5 \mathrm{a}$ & $25.8 \mathrm{a}$ \\
\hline Ethyl dodecanoate & $50.5 \mathrm{a}$ & $31.7 \mathrm{a}$ & $30.3 \mathrm{a}$ & $25.6 \mathrm{~b}$ & $21.0 \mathrm{a}$ & $20.3 \mathrm{a}$ & $17.1 \mathrm{~b}$ & $10.7 \mathrm{a}$ & $12.8 \mathrm{a}$ \\
\hline \multicolumn{10}{|l|}{ Alcohols } \\
\hline Isobutanol & $0.2 \mathrm{a}$ & $0.3 \mathrm{a}$ & $0.3 \mathrm{a}$ & $0.3 \mathrm{a}$ & $0.3 \mathrm{a}$ & $0.3 \mathrm{a}$ & $0.5 \mathrm{a}$ & $0.5 \mathrm{~b}$ & $0.5 \mathrm{a}$ \\
\hline & & & & & 42 & & & & \\
\hline
\end{tabular}




\begin{tabular}{|c|c|c|c|c|c|c|c|c|c|}
\hline 1-butanol & $1.9 \mathrm{a}$ & $2.4 \mathrm{a}$ & $2.4 \mathrm{a}$ & $2.4 \mathrm{a}$ & $2.5 \mathrm{a}$ & $2.4 \mathrm{a}$ & $2.3 \mathrm{a}$ & $2.4 \mathrm{a}$ & $2.3 \mathrm{a}$ \\
\hline Isoamylic alcohols & $92.4 \mathrm{a}$ & $116.7 \mathrm{~b}$ & $102.6 \mathrm{a}$ & $113.3 \mathrm{a}$ & $118.7 \mathrm{a}$ & $117.6 \mathrm{a}$ & $112.4 \mathrm{a}$ & $117.0 \mathrm{~b}$ & $112.3 \mathrm{a}$ \\
\hline 1-hexanol & $17.5 \mathrm{a}$ & $21.2 \mathrm{~b}$ & $19.0 \mathrm{a}$ & $19.6 \mathrm{a}$ & $20.3 \mathrm{a}$ & $20.3 \mathrm{a}$ & $19.5 \mathrm{a}$ & $19.1 \mathrm{a}$ & $19.2 \mathrm{a}$ \\
\hline trans-3-hexen-1-ol & $2.1 \mathrm{a}$ & $2.5 \mathrm{a}$ & $2.4 \mathrm{a}$ & $2.3 \mathrm{a}$ & $2.9 \mathrm{a}$ & $2.5 \mathrm{a}$ & $2.3 \mathrm{a}$ & $2.2 \mathrm{a}$ & $2.2 \mathrm{a}$ \\
\hline cis-3-hexen-1-ol & $1.7 \mathrm{a}$ & $2.1 \mathrm{~b}$ & $2.1 \mathrm{~b}$ & $2.1 \mathrm{a}$ & $2.1 \mathrm{a}$ & $2.3 \mathrm{a}$ & $2.0 \mathrm{a}$ & $2.0 \mathrm{a}$ & $2.2 \mathrm{~b}$ \\
\hline Benzyl alcohol & $0.4 \mathrm{a}$ & $0.4 \mathrm{a}$ & $0.4 \mathrm{a}$ & $0.4 \mathrm{a}$ & $0.4 \mathrm{a}$ & $0.4 \mathrm{a}$ & $0.4 \mathrm{a}$ & $0.4 \mathrm{a}$ & $0.4 \mathrm{a}$ \\
\hline$\beta$-phenylethyl alcohol & $3.8 \mathrm{a}$ & $3.8 \mathrm{a}$ & $3.7 \mathrm{a}$ & $3.5 \mathrm{a}$ & $3.4 \mathrm{a}$ & $3.9 \mathrm{a}$ & $3.9 \mathrm{a}$ & $3.2 \mathrm{a}$ & $3.7 \mathrm{a}$ \\
\hline \multicolumn{10}{|l|}{ Lactones/Furanic } \\
\hline Furfural & $5.2 \mathrm{a}$ & $6.1 \mathrm{~b}$ & $6.2 \mathrm{~b}$ & $4.8 \mathrm{~b}$ & $5.1 \mathrm{c}$ & $4.5 \mathrm{a}$ & $5.4 \mathrm{a}$ & $5.6 \mathrm{a}$ & $5.8 \mathrm{a}$ \\
\hline 5- methylfurfural & $2.2 \mathrm{a}$ & $2.4 \mathrm{a}$ & $2.5 \mathrm{a}$ & $2.4 \mathrm{a}$ & $2.3 \mathrm{a}$ & $2.4 \mathrm{a}$ & $2.4 \mathrm{a}$ & $2.2 \mathrm{a}$ & $2.5 \mathrm{a}$ \\
\hline$\gamma$-butyrolactone & $0.4 \mathrm{a}$ & $0.5 \mathrm{a}$ & $0.3 \mathrm{a}$ & $0.4 \mathrm{a}$ & $0.5 \mathrm{a}$ & $0.5 \mathrm{a}$ & $0.6 \mathrm{a}$ & $0.5 \mathrm{a}$ & $0.6 \mathrm{a}$ \\
\hline Furfuryl alcohol & $0.2 \mathrm{a}$ & $0.2 \mathrm{a}$ & $0.2 \mathrm{a}$ & $0.2 \mathrm{a}$ & $0.2 \mathrm{a}$ & $0.2 \mathrm{a}$ & $0.2 \mathrm{a}$ & $0.2 \mathrm{a}$ & $0.2 \mathrm{a}$ \\
\hline trans-whiskey lactone & $1.4 \mathrm{a}$ & $1.4 \mathrm{a}$ & $1.3 \mathrm{a}$ & $1.3 \mathrm{a}$ & $1.3 \mathrm{a}$ & $1.4 \mathrm{a}$ & $1.4 \mathrm{a}$ & $1.3 \mathrm{a}$ & $1.3 \mathrm{a}$ \\
\hline cis-whiskey lactone & $0.9 \mathrm{a}$ & $0.9 \mathrm{a}$ & $0.8 \mathrm{a}$ & $0.9 \mathrm{a}$ & $0.9 \mathrm{a}$ & $0.9 \mathrm{a}$ & $1.0 \mathrm{a}$ & $0.9 \mathrm{a}$ & $0.9 \mathrm{a}$ \\
\hline$\gamma$-nonalactone & $0.5 \mathrm{a}$ & $0.5 \mathrm{a}$ & $0.5 \mathrm{a}$ & $0.5 \mathrm{~b}$ & $0.5 \mathrm{a}$ & $0.5 \mathrm{~b}$ & $0.5 \mathrm{a}$ & $0.4 \mathrm{a}$ & $0.5 \mathrm{a}$ \\
\hline \multicolumn{10}{|l|}{ Volatile phenols } \\
\hline 2-methoxy,4-ethylphenol & $2.4 \mathrm{a}$ & $2.4 \mathrm{a}$ & $2.3 \mathrm{a}$ & $2.4 \mathrm{a}$ & $2.2 \mathrm{a}$ & $2.5 \mathrm{a}$ & $2.3 \mathrm{a}$ & $2.2 \mathrm{a}$ & $2.3 \mathrm{a}$ \\
\hline Eugenol & $0.3 \mathrm{a}$ & $0.3 \mathrm{a}$ & $0.3 \mathrm{a}$ & $0.3 \mathrm{ab}$ & $0.3 \mathrm{a}$ & $0.4 \mathrm{~b}$ & $0.3 \mathrm{a}$ & $0.3 \mathrm{a}$ & $0.3 \mathrm{a}$ \\
\hline 4-ethylphenol & $1.5 \mathrm{a}$ & $1.6 \mathrm{a}$ & $1.5 \mathrm{a}$ & $1.5 \mathrm{a}$ & $1.4 \mathrm{a}$ & $1.7 \mathrm{a}$ & $1.6 \mathrm{a}$ & $1.4 \mathrm{a}$ & $1.4 \mathrm{a}$ \\
\hline \multicolumn{10}{|l|}{ C13-norisoprenoids } \\
\hline$\beta$-damascenone & $3.4 \mathrm{a}$ & $3.8 \mathrm{a}$ & $3.4 \mathrm{a}$ & $3.6 \mathrm{a}$ & $3.6 \mathrm{a}$ & $3.8 \mathrm{a}$ & $3.3 \mathrm{a}$ & $3.1 \mathrm{a}$ & $3.2 \mathrm{a}$ \\
\hline$\alpha$-ionone & $5.4 \mathrm{a}$ & $5.5 \mathrm{a}$ & $4.9 \mathrm{a}$ & $5.2 \mathrm{a}$ & $5.2 \mathrm{a}$ & $5.5 \mathrm{a}$ & $4.7 \mathrm{a}$ & $4.3 \mathrm{a}$ & $4.5 \mathrm{a}$ \\
\hline$\beta$-ionone & $7.8 \mathrm{a}$ & $8.1 \mathrm{a}$ & $7.3 \mathrm{a}$ & $8.3 \mathrm{a}$ & $8.0 \mathrm{a}$ & $8.7 \mathrm{a}$ & $7.4 \mathrm{a}$ & $6.7 \mathrm{a}$ & $6.9 \mathrm{a}$ \\
\hline \multicolumn{10}{|l|}{ Acids } \\
\hline Hexanoic acid & $1.0 \mathrm{a}$ & $0.9 \mathrm{a}$ & $1.1 \mathrm{a}$ & $1.4 \mathrm{a}$ & $1.4 \mathrm{a}$ & $1.6 \mathrm{~b}$ & $1.3 \mathrm{~b}$ & $1.0 \mathrm{a}$ & $1.1 \mathrm{a}$ \\
\hline Octanoic acid & $2.5 \mathrm{a}$ & $2.1 \mathrm{a}$ & $2.6 \mathrm{a}$ & $3.6 \mathrm{~b}$ & $3.1 \mathrm{a}$ & $4.0 \mathrm{~b}$ & $3.0 \mathrm{a}$ & $2.5 \mathrm{a}$ & $2.4 \mathrm{a}$ \\
\hline Decanoic acid & nd & nd & nd & nd & nd & nd & nd & nd & nd \\
\hline
\end{tabular}

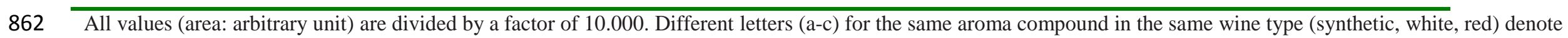

863 statistical differences among saliva types after applying LSD test 


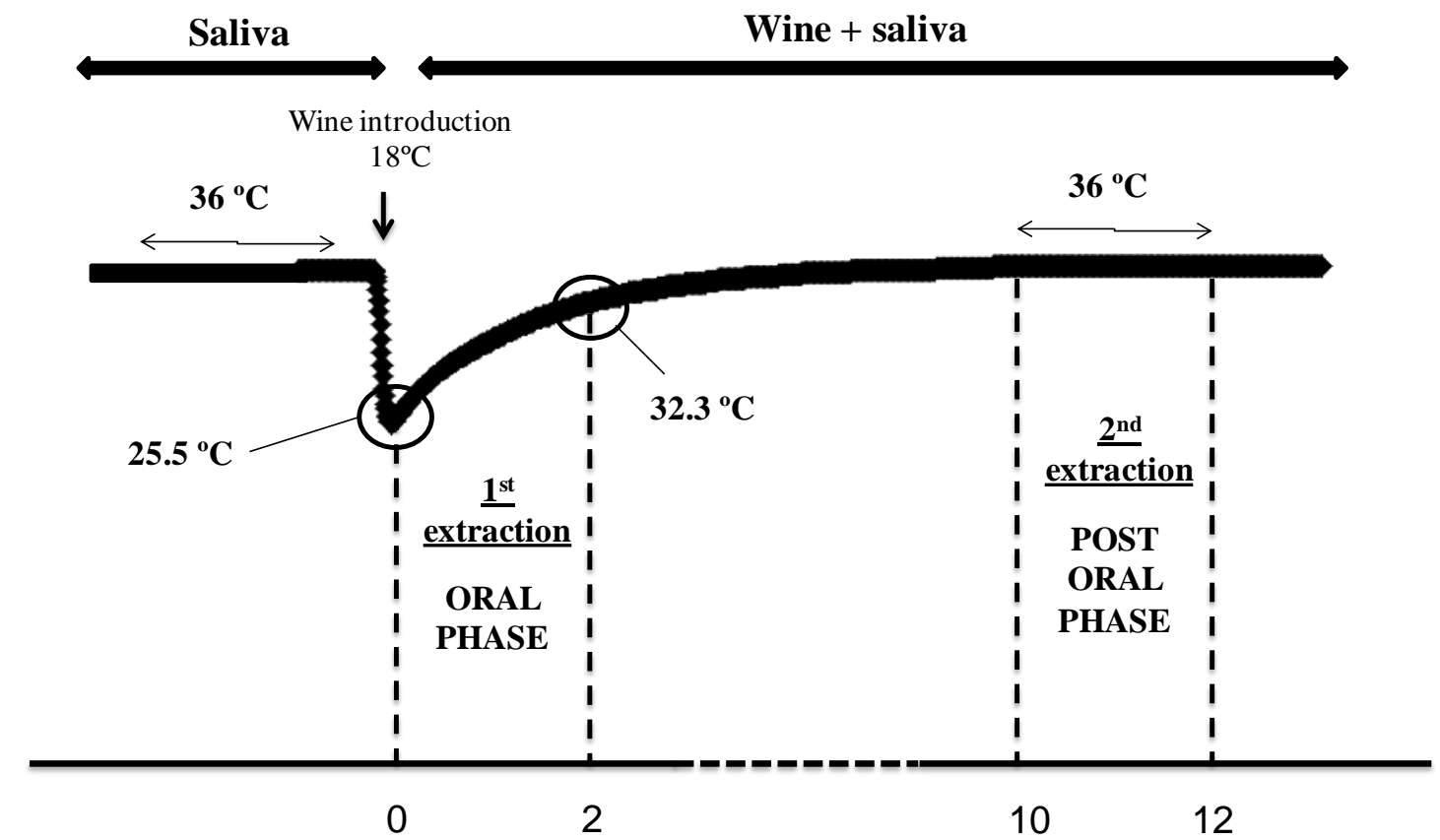

$867 \quad$ Figure 1

868

869 

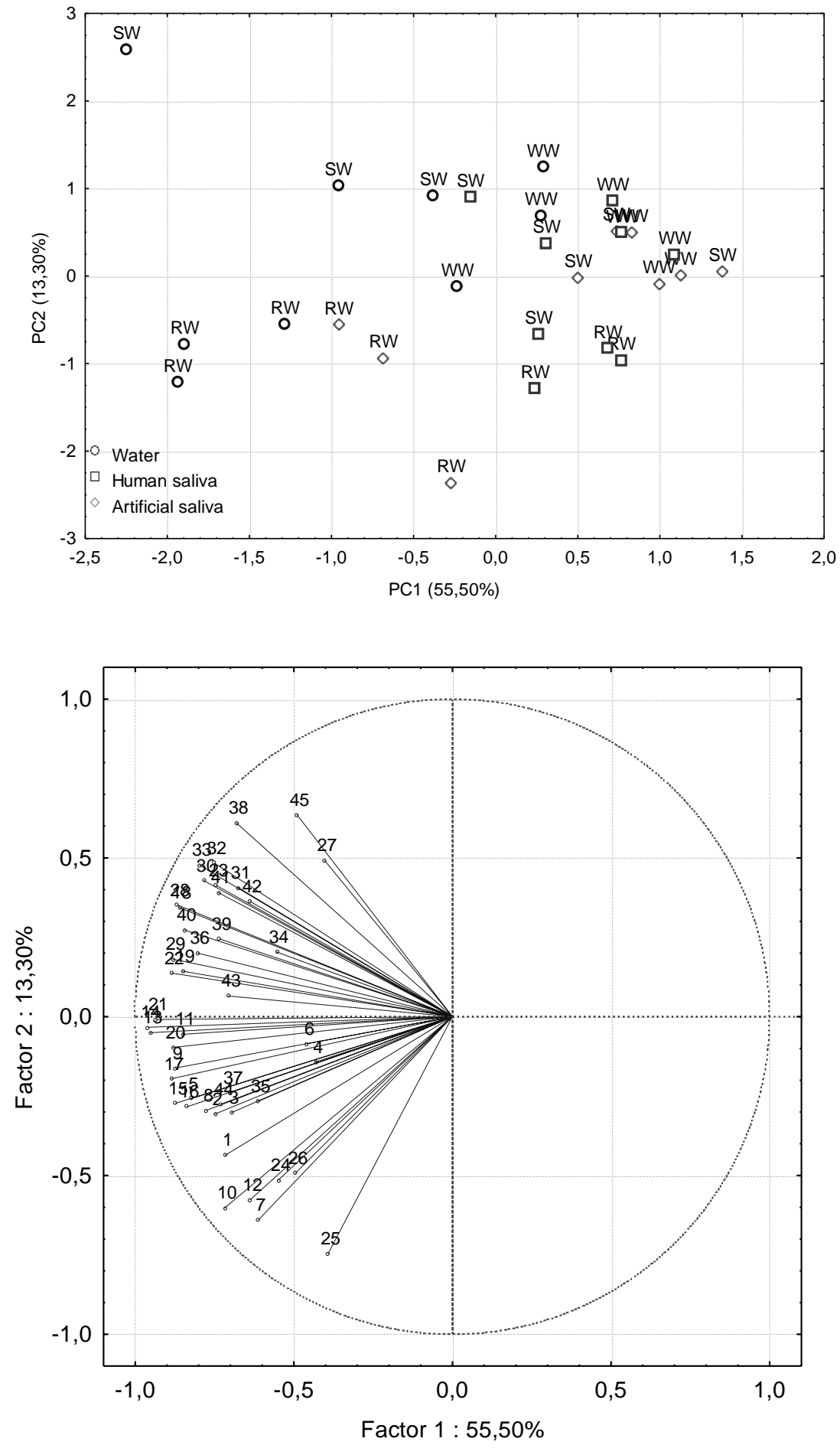

873

$874 \quad$ Figure 2 

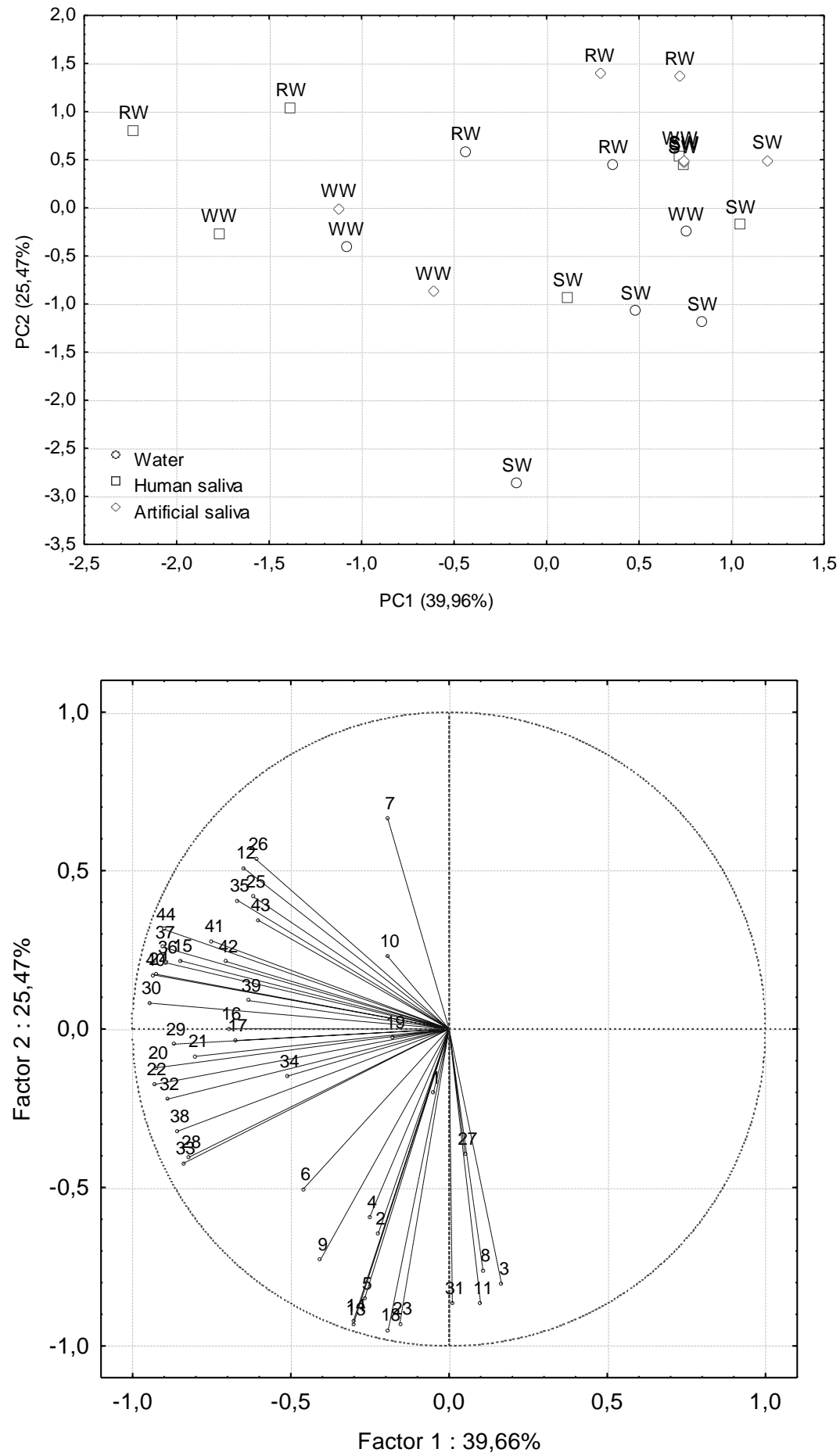

879

$880 \quad$ Figure 3 
881

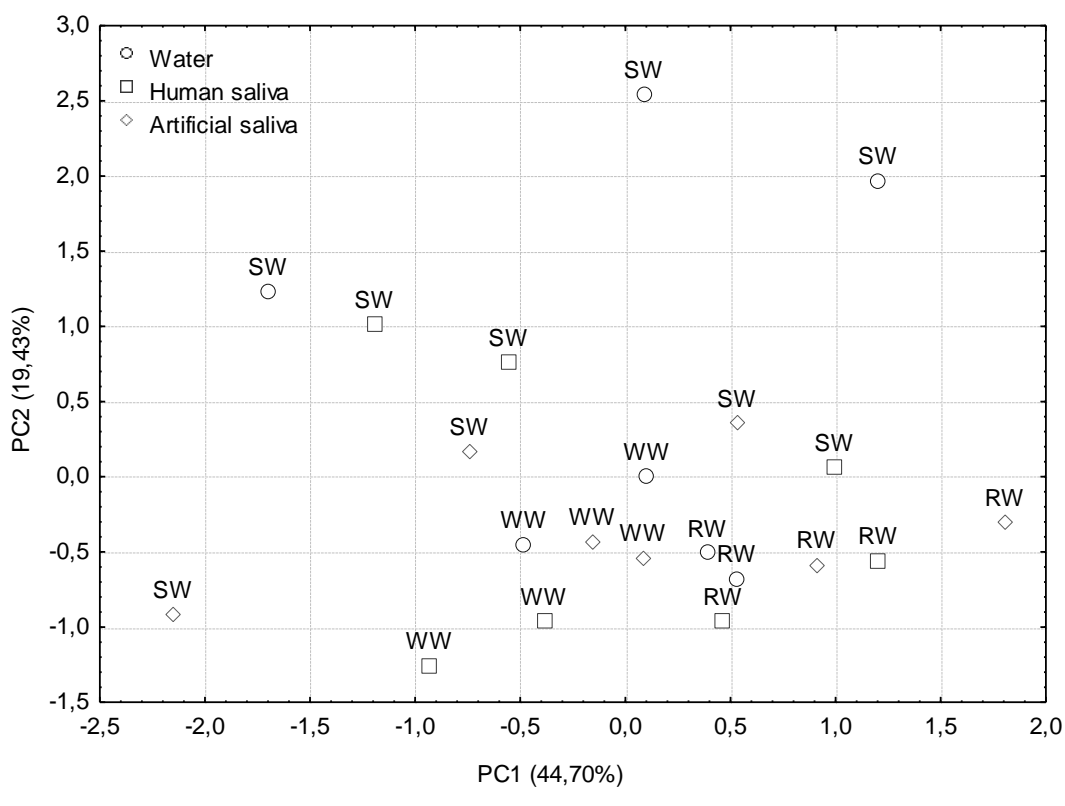

4b)

884

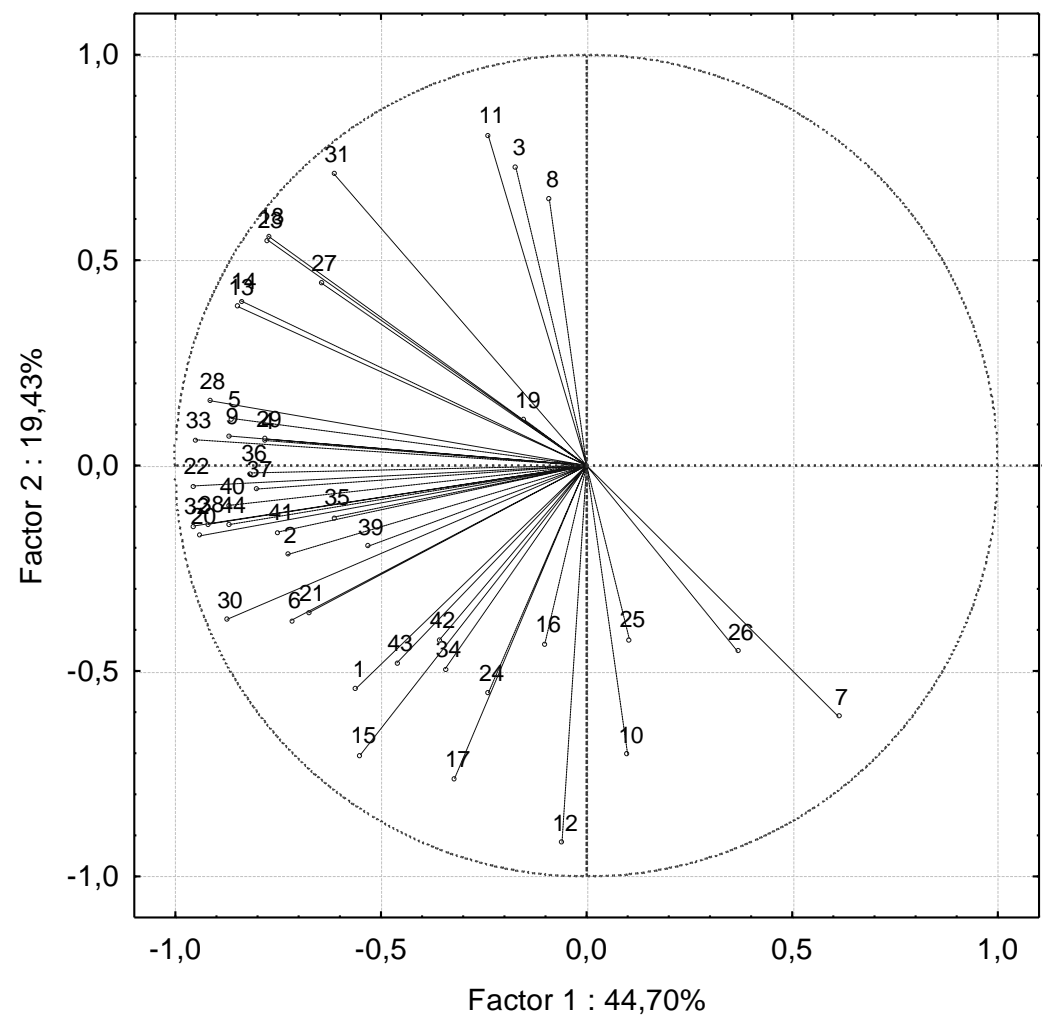

885

Figure 4 


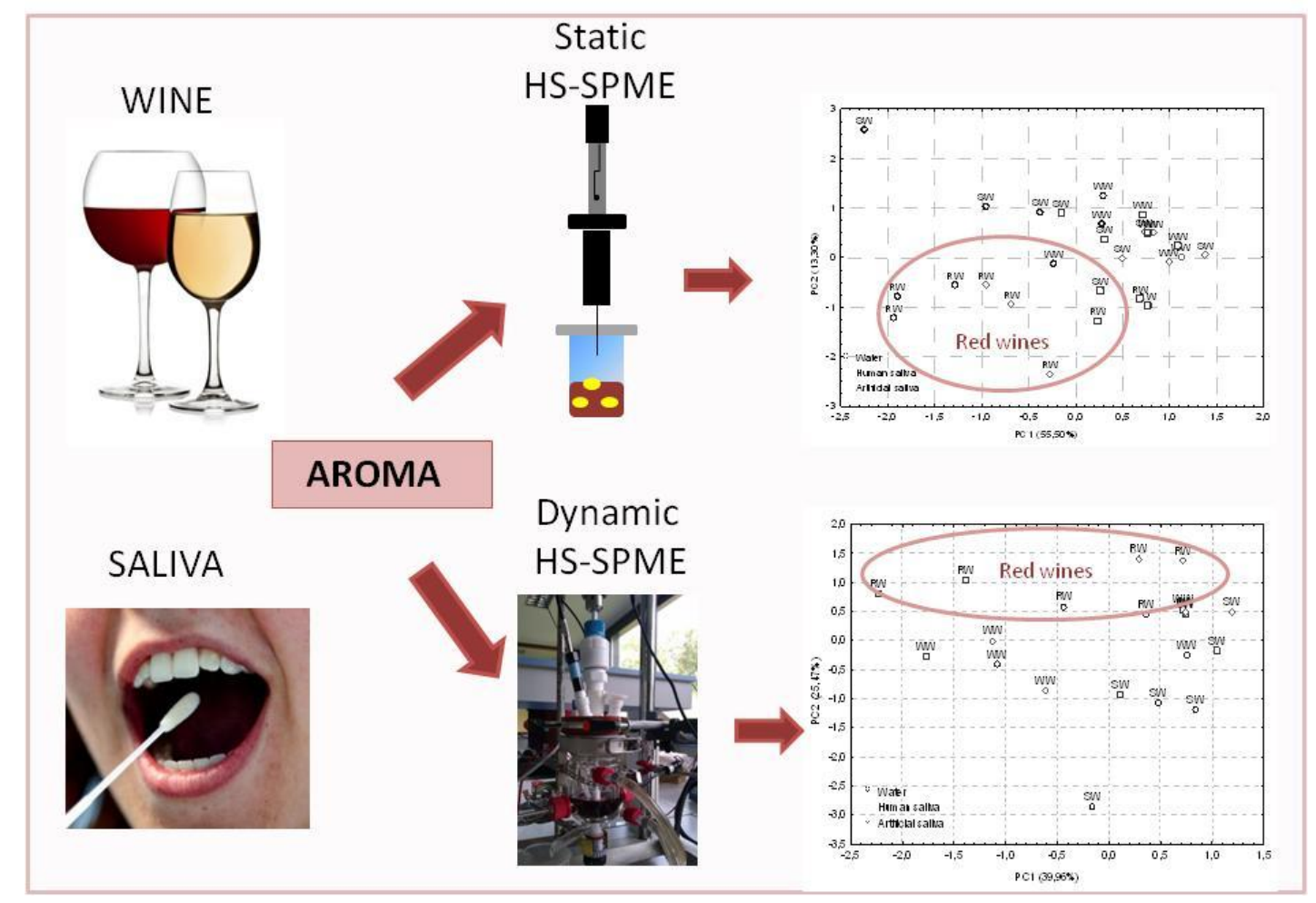

